\title{
Hygrothermal Risk in Museum Buildings Located in Moderate Climate
}

\author{
Joanna Ferdyn-Grygierek *D, Jan Kaczmarczyk, Monika Blaszczok, Piotr Lubina, Piotr Koper and \\ Anna Bulińska
}

Department of Heating, Ventilation and Dust Removal Technology, Faculty of Energy and Environmental Engineering, Silesian University of Technology, Konarskiego 20, 44-100 Gliwice, Poland; jan.kaczmarczyk@polsl.pl (J.K.); monika.blaszczok@polsl.pl (M.B.); piotr.lubina@polsl.pl (P.L.); piotr.koper@polsl.pl (P.K.); anna.bulinska@polsl.pl (A.B.)

* Correspondence: Joanna.Ferdyn-Grygierek@polsl.pl; Tel.: +48-32-237-29-12

Received: 24 November 2019; Accepted: 8 January 2020; Published: 10 January 2020

\begin{abstract}
Works of art are sensitive to environmental factors-mainly temperature and relative humidity - which, when stable, are generally recommended as ideal protection conditions, but in historical museum buildings, the required conditions are difficult to maintain, due to a lack of adequate heating, ventilation and air-conditioning systems. The paper presents the analysis of one-year measurements of temperature and relative humidity in three different museums in Poland. The aim of the research was to identify the risk to museum collections, due to unbalanced moisture loads and unstable indoor air temperatures, as well as to identify possible causes of fluctuations in these parameters. This article focuses on assessing the impact of variable external and internal loads on the hygrothermal parameters of indoor air. The profile of internal hygrothermal loads in exhibition halls varied over time, which resulted in a temporary variation of the indoor environmental parameters. The lack of appropriate systems, shaping the microclimate in the analyzed museums, and the lack of automatic control in existing devices did not allow to maintain the temperature and relative humidity within appropriate limits. In the museums, the maximum indoor temperature values were higher than those recommended in the requirements. Relative humidity values in all museums exceeded the recommended range both above and below.
\end{abstract}

Keywords: museum; microclimate; relative humidity; temperature; natural ventilation; energy consumption

\section{Introduction}

Inadequate internal environment conditions in museums are a major factor in the destruction of the collections stored in these institutions. Museums are often located in historical buildings. This situation significantly complicates the maintenance of the indoor environment. Historical buildings are usually naturally ventilated by infiltration through leaks in windows and doors. In moderate or cold climates heating systems which are used in museums are often simple installations, e.g., in Polish museums, these are typically high-temperature radiators, sometimes supplied with local control provided by thermostatic valves. As a result, the indoor environment in museums depends mainly on the heating system in the winter and on outdoor weather conditions in the summer [1]. Poor heating and ventilation systems do not provide the opportunity to obtain and maintain appropriate indoor microclimate conditions and pose a high risk of rapid ageing of museum exhibits. In such buildings, external climatic conditions have a great impact on the environmental parameter fluctuations. Also internal loads related to visitors and lighting can be very problematic as they cannot be compensated by operating the ventilation system. Heat and moisture gains from a large number of visitors are variable over time. Studies by Camuffo [2] and Kozlowski et al. [3-5] show that sudden and intense fluctuations in 
temperature (T) and relative humidity (RH) can cause stress to materials, and this, in turn, can cause irreversible changes in the physical and chemical properties that accelerate the destruction process of museum exhibits.

In the literature one can find different recommended ranges of air parameters under which exhibits should be stored [6-10]. They depend mainly on the type of material, the place of descent and the era in which they were created. The most well-known standards determining recommended air parameters in museums are the EN 15757 standard [6] and ASHRAE standard published by the American Society of Heating and Air-Conditioning Engineers [7]. The EN 15757 standard is particularly focused on RH variability and presents the concept of "proofed fluctuations" which was introduced by Michalski [11]. The standard recommends that objects are best preserved without departing from the historical climate if their condition is considered satisfactory. Most of the studies for the mixed collections in museums recommend temperatures in the range from 15 to $25^{\circ} \mathrm{C}$, with a variation from $\pm 2{ }^{\circ} \mathrm{C}$ to $\pm 5^{\circ} \mathrm{C}$ per day. Recommended relative humidity is in general $50 \%$, with acceptable daily fluctuations of $\pm 5 \% \mathrm{RH}$ or $\pm 10 \% \mathrm{RH}$ [8-10]. The range of tolerance in relative humidity and temperature changes, which do not cause unacceptable damage to museum exhibits, is still under discussion [12]. Maintaining a narrow range of temperature and relative humidity tolerance would require the application of advanced HVAC systems (with full air conditioning, i.e., heating, cooling, humidification and dehumidification systems). This results in high energy use in modern museums. The research presented in [8] shows that with a larger allowable RH and T variability limit, more energy can be saved.

The building envelope is the first filter of the outdoor climate; it buffers outside weather fluctuations and helps to maintain a stable indoor environment. HVAC systems, if present in the museum, provide additional control of the indoor air parameters [13]. Cantin et al. [14] show that the outdoor climate strongly influences the microclimate in historical buildings. This impact can be observed regardless of whether the building is equipped with air conditioning systems or not [15-17]. Bertolin, in her work [18] suggests that climate changes observed around the world have a significant impact on historical buildings and their collections.

Impact of the external climate on the indoor environment in museums or other historical sites, e.g., churches, are focused on dust and gaseous pollutants transport from outside to inside $[8,19-28]$ but also on the impact of hygrothermal external conditions on the indoor climate [29-35]. Recent studies [19,25], shows that a particularly unfavourable situation is when a museum is located in the centre of the city because pollution from traffic penetrates inside the museum. The destructive effect of pollution on museum exhibits is amplified by high temperature and humidity [24]. Other studies [8,23] shows that the pollutants are also transported to the indoor environment by visitors. In turn, Papadopoulos et al. [29] presented the variation of the indoor and the outdoor air temperature and relative humidity values in the Museum of Byzantine Culture in Thessaloniki for two typical days during the cooling season. They reported that in a typical summer day, the indoor air conditions cannot be characterized as satisfactory, mainly due to the high relative humidity levels. The paper by Sciurpi et al. [31] presents the results of a one-year record of temperature and relative humidity, regarding a room and its showcases. The elaboration and analysis of the microclimatic data have been carried out according to the Italian standards. The authors stated that the temperature and relative humidity were not acceptable for protecting exhibits. The work by Klein et al. [32], presents the results of three years' continuous monitoring of environmental conditions in the New York Metropolitan Museum of Art. The precise monitoring enabled observation of subtle changes in air quality trends and the impact of visitors on the microclimate conditions.

A good understanding of the outdoor weather conditions and indoor hygrothermal loads' influence on indoor microclimates is crucial for the analyses of the speed of museum exhibit ageing. A state-of art review of indoor air measurements in museums has shown that there is still a need for reference comprehensive case studies in different climates for various museum building construction design. Especially in buildings with no HVAC systems, where indoor air parameters cannot be controlled, measurements allow for the first verification of risk to museum collections [22]. Comprehensive studies 
can be found in the literature [36-38]. Martens [36] presents a study of the microclimate conditions in 21 museum buildings, taking into account one-year monitoring data. Measurements, carried out in years: 2002 to 2008, were performed in museums located in West Europe (Netherlands or Belgium). The HVAC systems ranged from none to full systems. Camuffo et al. [37] presented research on four museums (located in West and North Europe) but only for selected days in winter and summer. One-year monitoring of indoor air parameters in two museums, located one in Italy and other in Sweden, can be found in [38].

The main objective of this study was to identify the risk to museum collections due to moisture loads and unstable indoor air temperature as well as to identify possible causes of fluctuations in these parameters. An important aim of this study was to identify the impact of external and internal loads on the hygrothermal parameters of indoor air. Data from the one-year monitoring of indoor air parameters in three museums located in Central Europe was used for the analysis. This work is arranged as follows: Section 2 describes the case study, the measurement setup and data collection procedure; Section 3 shows the evaluation of results, statistical analysis and discussion; Section 4 presents the conclusions and suggested future research projects.

\section{Method}

The measurements were carried out in three museums located in the Upper Silesia region, in the southern part of Poland. This region has a temperate climate with relatively cold winters and warm summers, which is greatly influenced by oceanic air currents from the west, cold polar air from Russia and Scandinavia, but also warmer, sub-tropical air from the south.

The first museum is located in a building from 1930, which was built to accommodate a museum (museum A). The two other museums are located in historical buildings (museum B and C). In museum A (Figure 1), exhibitions are collected in large rooms located on three floors of the building. The exhibition named flora and fauna (floor area $250 \mathrm{~m}^{2}$ ) and temporary exhibitions $\left(170 \mathrm{~m}^{2}\right)$ are located on the first floor. The ethnography exhibition $\left(860 \mathrm{~m}^{2}\right)$ is located on the second floor, and the painting gallery $\left(630 \mathrm{~m}^{2}\right)$ and modern art exhibition (area of $410 \mathrm{~m}^{2}$ ) are on the third floor. Inside the building, there is a large staircase connecting all floors. Museum B is located in an old town hall, erected in 1822 (Figure 2a). In this museum, an exhibition presenting the coal mine industry is located in the building's cellar, on the first floor there is a temporary exhibition area, and on the second floor there are regional history and culture, as well as craft history exhibitions. Each type of exhibition is presented in two or more interconnected rooms. The total exhibit area ions equals $1740 \mathrm{~m}^{2}$. Museum $C$ is located in a castle from the 14th century (Figure 2b), with exhibitions located on three floors and in the tower. On each floor, there is a series of interconnected exhibition rooms. On the first floor, an archaeological exhibition (floor area $150 \mathrm{~m}^{2}$ ) is located, on the second floor a historical exhibition $\left(150 \mathrm{~m}^{2}\right)$ and at the third floor an ethnographical exhibition $\left(190 \mathrm{~m}^{2}\right)$. The tower is reserved for temporary exhibitions $\left(40 \mathrm{~m}^{2}\right)$. Table 1 presents the technical specifications of the museum buildings.

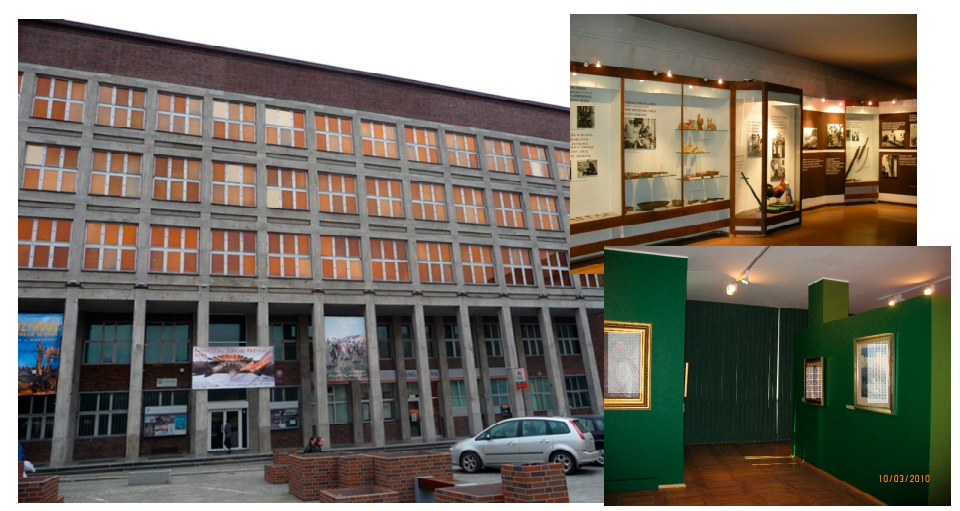

Figure 1. Museum A-view of the main entrance and the ethnography and painting exhibitions. 


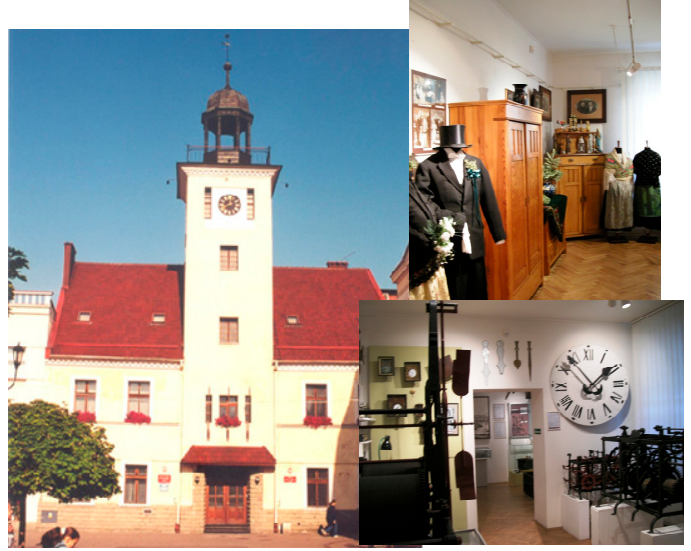

(a)

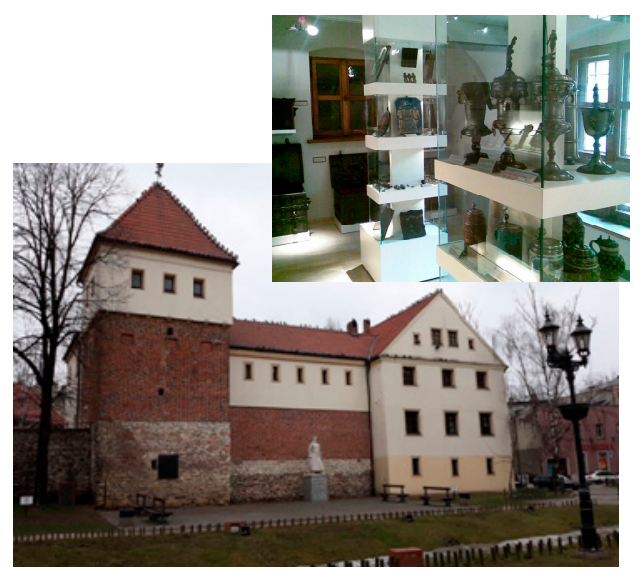

(b)

Figure 2. Museum B (old town hall)—view of the main entrance and the ethnography and craftsmanship exhibitions (a) and Museum C (so-called Piast's Castle) (b).

Table 1. Technical data of the museum buildings.

\begin{tabular}{|c|c|c|c|}
\hline & Museum A & Museum B & Museum C \\
\hline \multicolumn{4}{|c|}{ Heavy construction without thermal insulation } \\
\hline $\begin{array}{l}\text { External } \\
\text { walls }\end{array}$ & $\begin{array}{c}\text { Ferroconcrete } 38 \mathrm{~cm} \text { or brick } 38 \mathrm{~cm} \\
\text { (depending on the wall) } \\
\mathrm{U}=1.5-2.5 \mathrm{~W} / \mathrm{m}^{2} \mathrm{~K}\end{array}$ & $\begin{array}{l}\text { Brick } 50 \text { or } 38 \mathrm{~cm} \text { (depending on the } \\
\text { wall) } \mathrm{U}=1.0-1.3 \mathrm{~W} / \mathrm{m}^{2} \mathrm{~K}\end{array}$ & $\begin{array}{c}\text { Stone (only ground floor) and } \\
\text { brick, the thickness is } 2.1-2.4 \mathrm{~m} \\
\text { at zero level and decreases on } \\
\text { the upper floors to } 1.0 \mathrm{~m}, \\
\mathrm{U}=0.6-1.3 \mathrm{~W} / \mathrm{m}^{2} \mathrm{~K}\end{array}$ \\
\hline $\begin{array}{l}\text { Sun } \\
\text { protection }\end{array}$ & $\begin{array}{l}\text { Plasterboard walls set up in parallel } \\
\text { to the external walls, windows in } \\
\text { western façade covered with } \\
\text { anti-reflective coating }\end{array}$ & Internal blinds or curtains & $\begin{array}{c}\text { Shades placed between } \\
\text { window panes }\end{array}$ \\
\hline $\begin{array}{l}\text { Heating } \\
\text { system }\end{array}$ & $\begin{array}{l}\text { Old radiators, not modernized for } \\
\text { many years (some equipped with } \\
\text { thermostatic valves, which are set } \\
\text { at } 20^{\circ} \mathrm{C} \text { ) }\end{array}$ & $\begin{array}{l}\text { Radiators equipped with } \\
\text { thermostatic valves (set point } 20^{\circ} \mathrm{C} \text { ) }\end{array}$ & $\begin{array}{l}\text { Generally air-heater system with } \\
\text { a local control system, in some } \\
\text { rooms radiators equipped with } \\
\text { thermostatic valves } \\
\text { (set point } 20-22^{\circ} \mathrm{C} \text { ) }\end{array}$ \\
\hline & \multicolumn{3}{|c|}{ Natural ventilation } \\
\hline $\begin{array}{l}\text { Ventilation } \\
\text { system }\end{array}$ & $\begin{array}{c}\text { Airflow only through cracks in } \\
\text { windows and doors. No ventilation } \\
\text { ducts }{ }^{1}\end{array}$ & $\begin{array}{l}\text { Airflow through doors and window } \\
\text { leakages and gravity ventilation } \\
\text { ducts (most rooms are equipped } \\
\text { with ducts) }\end{array}$ & $\begin{array}{l}\text { Airflow through doors and } \\
\text { window leakages and gravity } \\
\text { ventilation ducts (only a few } \\
\text { rooms are equipped with ducts) }\end{array}$ \\
\hline
\end{tabular}

${ }^{1}$ The operation of the ventilation system is described in ref. [39].

Most exhibition rooms in the museums contained mixed collections (e.g., paper, textile, wood and metal objects), and only museum A had dedicated rooms for paintings and for flora and fauna. The museums were open to visitors all week, except Mondays (depending on the day of the week, from 4 to $7 \mathrm{~h}$ per day). 


\subsection{Measurement of the Indoor Climate}

Measurements of air temperature and relative humidity were carried out at representative points, which were located away from sources of heat, windows and doors. Nine sensors (type $\mathrm{Si}$ and $\mathrm{Ai}$, see Table 2) were placed in Museum A, eight sensors (type PSi and Ai) in Museum B and nine sensors (type PSi and Ai) in Museum C. A larger number of sensors have been placed in the large exhibition halls of Museum A. The sensors were located in places where they did not disturb the exposition of monuments and were not exposed to theft or damage (e.g., on walls, on showcases, under the exhibition tables). Example locations are presented in Figure 3. One of the sensors in Museum A (sensor S2), due to the lack of other options, was located on the plasterboard wall serving as solar protection (the impact of this location is discussed in Section 3.4).

Table 2. Technical data of sensors.

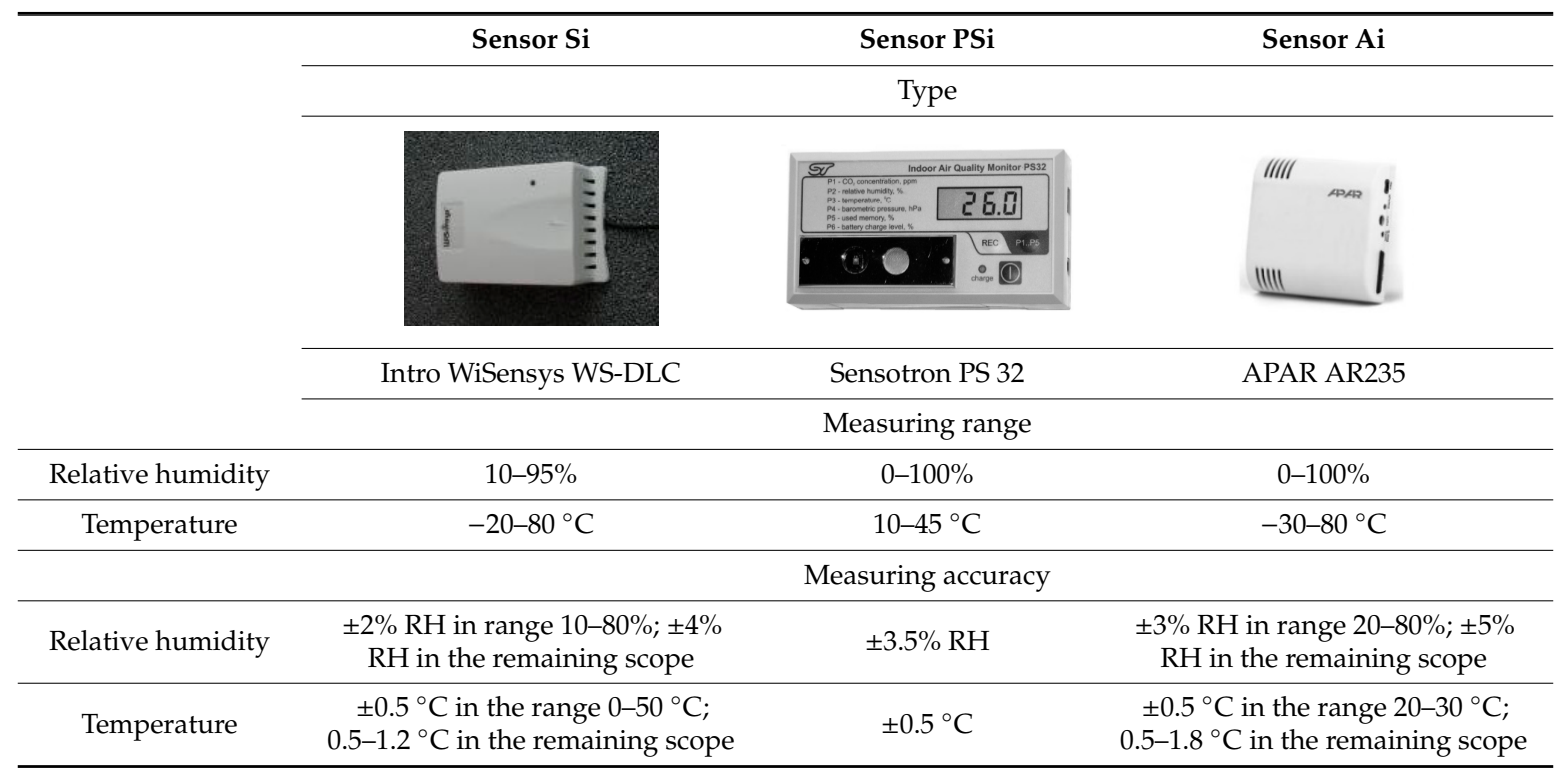

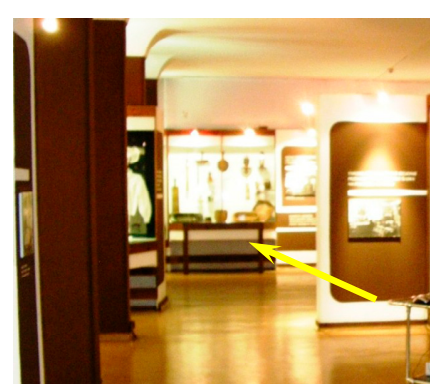

(a)

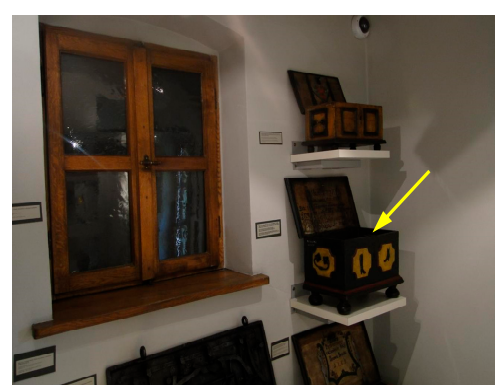

(b)

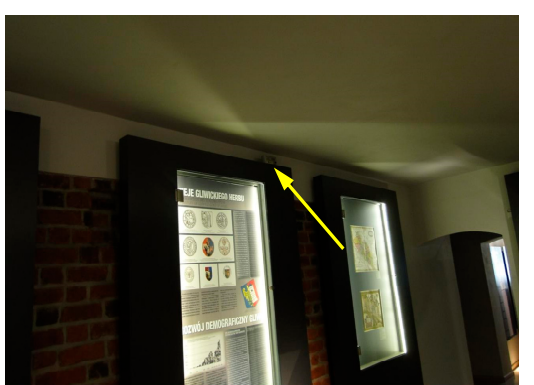

(c)

Figure 3. An example of the sensors' locations in Museum A (a) and Museum C (b,c).

The details on the sensors used in the study are given in Table 2. The measurement accuracy in the ranges recorded in this measurement met the requirements of EN 15758 and EN 16242 standards $[40,41]$ on the conservation of cultural heritage. In order to compare the readings of the sensors, their intercalibration was performed before and after the measurements. Measurements in the museums lasted a whole year. Data were recorded at 5 min intervals.

\subsection{Measurement of the External Climate}

Knowledge of temporary external climate data is one of the basic conditions for the analysis of results. Detailed climatic conditions were recorded outside of Museum C, using the Davis Health 
EnviroMonitor weather station [42], with 15-min intervals between data collection. Museums A and B are approx. $20 \mathrm{~km}$ away from the weather station, therefore the temperature and relative humidity of outdoor air at these museums were additionally measured using APAR AR235 sensors (Table 2).

\subsection{Measurement of Internal Heat Gains}

The dominant internal heat source in museum buildings is heat gained from people and from lighting. Typical values of heat flux emitted by these sources can be found in the literature, design guides and standards [43-47]. Unfortunately, heat gains do not occur constantly and depend on the opening hours of the museum, the season of the year and, above all, on the number of visitors and the time they spend in individual rooms [48].

In each of the analyzed museums, a detailed study of the number of people visiting individual exhibitions was carried out for several days, recording the number of people and the time of entry and exit from the room. These studies were performed in various museums on different days of the week. This allowed determining the real-time profiles of people staying in the examined objects.

In the case of a lighting system - an inventory of light sources was made in each exhibition hall. During detailed tests of visitors' attendance, it was also recorded whether the lighting was turned off after visitors left the room.

\section{Results and Discussion}

Recording of air temperature and humidity allowed for analysis of the variations of these parameters in studied museums. Figures 4 and 5 present the median, minimum and maximum values of temperature and relative humidity in the whole measurement year for individual sensors' location. The corresponding $25 \%$ and $75 \%$ percentiles are also presented. Annual median air temperature ranged from 19 to $22{ }^{\circ} \mathrm{C}$ and relative humidity from 40 to $55 \%$. It can be observed that the distribution of environmental parameters varied within the museums. Since all museums were equipped with a heating system operating in winter and only one room was equipped with air conditioning the data were analyzed for these seasons separately and presented in Table 3. The results in Table 3 clearly show that, compared to the winter season, in summer not only median values are higher, but also the variation of both temperature and relative humidity are larger, which is indicated by the percentiles.

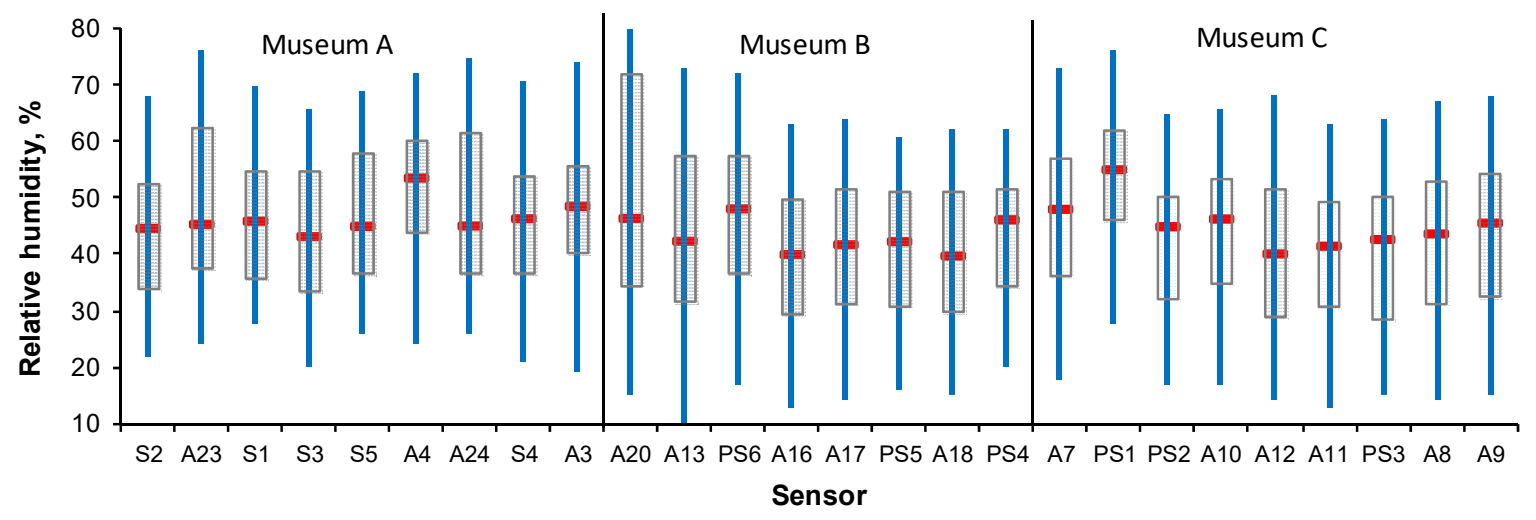

Figure 4. Annual median (in red), minimum and maximum values (in blue) and 25-75 percentiles (box in grey) of air relative humidity in all measuring points. 


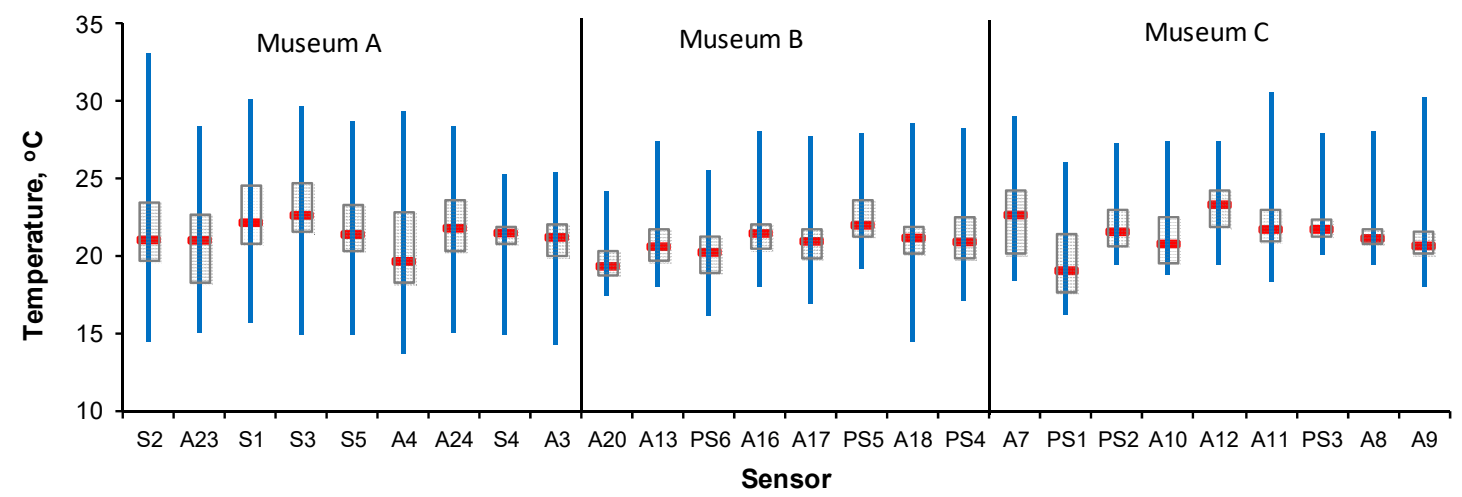

Figure 5. Annual median (in red), minimum and maximum values (in blue) and 25-75 percentiles (box in grey) of air temperature in all measuring points.

Table 3. Median (M) and 75\% and $25 \%$ percentiles $(\mathrm{P})$ of temperature and relative humidity at given measuring locations during the heating period (winter, October-April) and the non-heating period (summer, May-September).

\begin{tabular}{|c|c|c|c|c|c|c|c|c|c|c|}
\hline & & & \multicolumn{4}{|c|}{ Temperature, ${ }^{\circ} \mathrm{C}$} & \multicolumn{4}{|c|}{ Relative Humidity, \% } \\
\hline \multicolumn{2}{|c|}{ Location } & \multirow[t]{2}{*}{ Sensor } & \multicolumn{2}{|c|}{ Winter } & \multicolumn{2}{|c|}{ Summer } & \multicolumn{2}{|c|}{ Winter } & \multicolumn{2}{|c|}{ Summer } \\
\hline & & & $\mathbf{M}$ & P 75/25 & $\mathbf{M}$ & P 75/25 & $\mathbf{M}$ & P 75/25 & $\mathbf{M}$ & P 75/25 \\
\hline \multicolumn{11}{|c|}{ Museum A } \\
\hline \multirow{2}{*}{ First floor } & Flora \& fauna & $\mathrm{S} 2$ & 20.7 & $22.0 / 19.7$ & 23.3 & $25.0 / 19.7$ & 35 & $44 / 32$ & 53 & $57 / 49$ \\
\hline & Temporary & A23 & 20.1 & $21.5 / 17.9$ & 22.4 & $24.0 / 19.1$ & 38 & $43 / 34$ & 63 & $67 / 61$ \\
\hline \multirow{5}{*}{ Second floor } & \multirow{5}{*}{ Ethnography } & S1 & 21.7 & $23.6 / 20.8$ & 23.8 & $25.3 / 20.3$ & 38 & $46 / 34$ & 56 & $59 / 53$ \\
\hline & & S3 & 22.4 & $24.2 / 21.8$ & 23.7 & $25.2 / 20.2$ & 35 & $43 / 32$ & 55 & $59 / 53$ \\
\hline & & S5 & 21.1 & $22.6 / 20.5$ & 23.0 & $24.3 / 19.6$ & 38 & $44 / 34$ & 59 & $62 / 56$ \\
\hline & & A4 & 19.0 & 20.4/17.4 & 23.0 & 25.0/19.1 & 47 & $53 / 41$ & 61 & $64 / 57$ \\
\hline & & A24 & 21.6 & $23.3 / 20.9$ & 22.9 & 24.6/19.3 & 37 & $41 / 35$ & 62 & $66 / 59$ \\
\hline \multirow{2}{*}{ Third floor } & \multirow{2}{*}{$\begin{array}{l}\text { Painting } \\
\text { gallery }\end{array}$} & S4 & 21.5 & $22.2 / 21.0$ & 21.5 & 21.6/19.8 & 39 & $46 / 30$ & 54 & $59 / 50$ \\
\hline & & A3 & 20.8 & $21.7 / 20.1$ & 21.9 & $22.5 / 19.5$ & 42 & $49 / 35$ & 56 & $61 / 51$ \\
\hline \multicolumn{11}{|c|}{ Museum B } \\
\hline Basem. & Mining exhib. & A20 & 19.2 & 20.1/18.7 & 19.5 & $20.4 / 18.9$ & 37 & $43 / 27$ & 75 & $80 / 67$ \\
\hline \multirow{2}{*}{ Ground floor } & \multirow{2}{*}{ Temporary } & A13 & 20.0 & 20.8/19.4 & 21.8 & $23.6 / 20.6$ & 34 & $39 / 25$ & 59 & $63 / 55$ \\
\hline & & PS6 & 19.2 & $20.5 / 18.5$ & 21.4 & $22.9 / 20.2$ & 41 & $47 / 31$ & 58 & $63 / 54$ \\
\hline \multirow{5}{*}{ First floor } & \multirow{3}{*}{$\begin{array}{l}\text { Craftsmanship } \\
\text { exhibitions }\end{array}$} & A16 & 20.8 & $21.5 / 20.1$ & 23.5 & $25.3 / 21.7$ & 31 & $38 / 24$ & 50 & $54 / 48$ \\
\hline & & A17 & 20.1 & 21.0/19.5 & 23.0 & $24.8 / 21.1$ & 33 & $39 / 25$ & 52 & $56 / 50$ \\
\hline & & PS5 & 21.6 & $22.4 / 21.1$ & 23.9 & $25.2 / 21.7$ & 31 & $37 / 25$ & 51 & $54 / 48$ \\
\hline & \multirow{2}{*}{ Ethnography } & A18 & 20.7 & 21.4/19.5 & 23.7 & $25.3 / 21.0$ & 33 & $39 / 25$ & 53 & $55 / 50$ \\
\hline & & PS4 & 20.1 & 20.9/19.1 & 23.4 & $25.3 / 21.2$ & 36 & $43 / 30$ & 52 & $54 / 49$ \\
\hline \multicolumn{11}{|c|}{ Museum C } \\
\hline \multirow{2}{*}{ Ground floor } & \multirow{2}{*}{$\begin{array}{c}\text { Archaeological } \\
\text { exhibitions }\end{array}$} & A7 & 20.4 & $22.5 / 20.0$ & 24.3 & $25.4 / 23.0$ & 38 & $45 / 30$ & 57 & $63 / 53$ \\
\hline & & PS1 & 17.8 & $18.7 / 17.2$ & 21.6 & $23.0 / 20.0$ & 48 & $53 / 43$ & 63 & $67 / 59$ \\
\hline \multirow{3}{*}{ First floor } & \multirow{3}{*}{$\begin{array}{l}\text { Historical } \\
\text { exhibitions }\end{array}$} & PS2 & 20.8 & $21.4 / 20.3$ & 23.1 & $24.3 / 21.8$ & 33 & $42 / 27$ & 51 & $54 / 48$ \\
\hline & & A10 & 19.6 & $20.4 / 19.4$ & 23.2 & $24.5 / 21.7$ & 36 & $44 / 29$ & 54 & $57 / 21$ \\
\hline & & A12 & 22.4 & $23.8 / 21.0$ & 24.0 & $24.7 / 22.2$ & 30 & $37 / 24$ & 52 & $56 / 50$ \\
\hline \multirow{3}{*}{ Second floor } & \multirow{3}{*}{ Ethnography } & A11 & 21.0 & $21.5 / 20.8$ & 23.7 & $25.7 / 22.3$ & 32 & $39 / 26$ & 50 & $53 / 48$ \\
\hline & & PS3 & 21.6 & $22.0 / 21.2$ & 22.3 & $24.5 / 21.4$ & 31 & $41 / 25$ & 51 & $54 / 49$ \\
\hline & & A8 & 20.9 & $21.2 / 20.7$ & 22.7 & 24.6/21.1 & 34 & $41 / 26$ & 53 & $57 / 51$ \\
\hline Tower & Temporary & A9 & 20.5 & 20.8/20.1 & 22.4 & $24.9 / 20.3$ & 35 & $43 / 27$ & 55 & $58 / 52$ \\
\hline External cl & nate (range) & & -1 & $3-27.7$ & & -33.5 & & -94 & & -84 \\
\hline
\end{tabular}




\subsection{Indoor Parameter Variation}

The changes in the recorded indoor air parameters were subjected to analysis. Bearing in mind the requirements determined by the ASHRAE standard on museums [7], Performance Index (PI) values for all measuring locations were determined (Table 4). This index expresses the percentage of the time, in which the measured parameters are within the reference target. PI value is not imposed by any standard but is often used to analyze the microclimate in museums [31,49-51]. ASHRAE's chapter 23 [7] states a small risk for exhibits limiting short-term fluctuations to $\pm 2{ }^{\circ} \mathrm{C}$ for temperature and to $\pm 5 \%$ or $\pm 10 \%$ for relative humidity. Therefore, in this study, PI indicates the percentage of the time, in which the daily temperature fluctuations are smaller than $\pm 2{ }^{\circ} \mathrm{C}$, and daily relative humidity fluctuations are smaller than $\pm 5 \%$ or $\pm 10 \%$.

Table 4. The share of the year when the amplitude of daily values of indoor temperature or relative humidity is less than the maximum recommended value, according to ASHRAE standard [7] and the maximum daily temperature and relative humidity amplitude recorded during the whole year.

\begin{tabular}{|c|c|c|c|c|c|c|c|}
\hline \multirow{2}{*}{\multicolumn{2}{|c|}{ Location }} & \multirow{2}{*}{ Sensor } & \multicolumn{3}{|c|}{ Performance Index PI, \% of Time } & \multicolumn{2}{|c|}{ Max } \\
\hline & & & \multirow{2}{*}{$\begin{array}{l}\Delta \mathrm{T} \leq 2{ }^{\circ} \mathrm{C} \\
\text { Museum A }\end{array}$} & \multirow[t]{2}{*}{$\Delta \mathrm{RH} \leq 5 \%$} & \multirow[t]{2}{*}{$\Delta \mathrm{RH} \leq \mathbf{1 0} \%$} & \multirow[t]{2}{*}{$\Delta \mathrm{T},{ }^{\circ} \mathrm{C}$} & \multirow[t]{2}{*}{$\Delta \mathrm{RH}, \%$} \\
\hline & & & & & & & \\
\hline \multirow{2}{*}{ First floor } & Flora and fauna & $\mathrm{S} 2$ & 73 & 60 & 88 & 6.4 & 20 \\
\hline & Temporary & A23 & 69 & 84 & 98 & 5.3 & 21 \\
\hline \multirow{5}{*}{ Second floor } & \multirow{5}{*}{ Ethnography } & S1 & 93 & 96 & 100 & 3.2 & 8 \\
\hline & & S3 & 98 & 92 & 99 & 4.4 & 14 \\
\hline & & S5 & 97 & 86 & 97 & 3.2 & 15 \\
\hline & & A4 & 97 & 82 & 96 & 3.7 & 17 \\
\hline & & A24 & 99 & 89 & 98 & 3.6 & 16 \\
\hline \multirow{2}{*}{ Third floor } & \multirow{2}{*}{ Painting gallery } & S4 & 94 & 36 & 43 & 3.2 & 22 \\
\hline & & A3 & 89 & 71 & 83 & 4.1 & 19 \\
\hline \multicolumn{8}{|c|}{ Museum B } \\
\hline Basement & Mining exhibition & A20 & 87 & 72 & 97 & 4.8 & 31 \\
\hline \multirow{2}{*}{ Ground floor } & \multirow{2}{*}{ Temporary } & A13 & 97 & 53 & 91 & 2.7 & 18 \\
\hline & & PS6 & 97 & 60 & 89 & 4.4 & 26 \\
\hline \multirow{5}{*}{ First floor } & \multirow{3}{*}{$\begin{array}{l}\text { Craftsmanship } \\
\text { exhibitions }\end{array}$} & A16 & 100 & 81 & 98 & 1.7 & 18 \\
\hline & & A17 & 99 & 80 & 97 & 2.5 & 18 \\
\hline & & PS5 & 99 & 81 & 98 & 3.5 & 17 \\
\hline & \multirow{2}{*}{ Ethnography } & A18 & 96 & 83 & 98 & 6.9 & 23 \\
\hline & & PS4 & 96 & 82 & 98 & 4.4 & 25 \\
\hline \multicolumn{8}{|c|}{ Museum C } \\
\hline \multirow{2}{*}{ Ground floor } & \multirow{2}{*}{$\begin{array}{l}\text { Archaeological } \\
\text { exhibitions }\end{array}$} & A7 & 86 & 36 & 80 & 6.8 & 29 \\
\hline & & PS1 & 99 & 49 & 86 & 2.9 & 26 \\
\hline \multirow{3}{*}{ First floor } & \multirow{3}{*}{$\begin{array}{l}\text { Historical } \\
\text { exhibitions }\end{array}$} & PS2 & 99 & 70 & 97 & 3.3 & 15 \\
\hline & & A10 & 100 & 76 & 97 & 2.0 & 15 \\
\hline & & A12 & 96 & 79 & 98 & 3.1 & 13 \\
\hline \multirow{3}{*}{ Second floor } & \multirow{3}{*}{ Ethnography } & A11 & 98 & 70 & 98 & 2.5 & 14 \\
\hline & & PS3 & 98 & 75 & 98 & 3.0 & 23 \\
\hline & & A8 & 99 & 70 & 98 & 4.8 & 20 \\
\hline Tower & Temporary & A9 & 97 & 65 & 98 & 3.4 & 19 \\
\hline
\end{tabular}

In addition, the monitoring results were subjected to the requirements of EN 15757 standard [6], determining the annual change cycle of RH based on of 30-day moving average (Figure 6). 


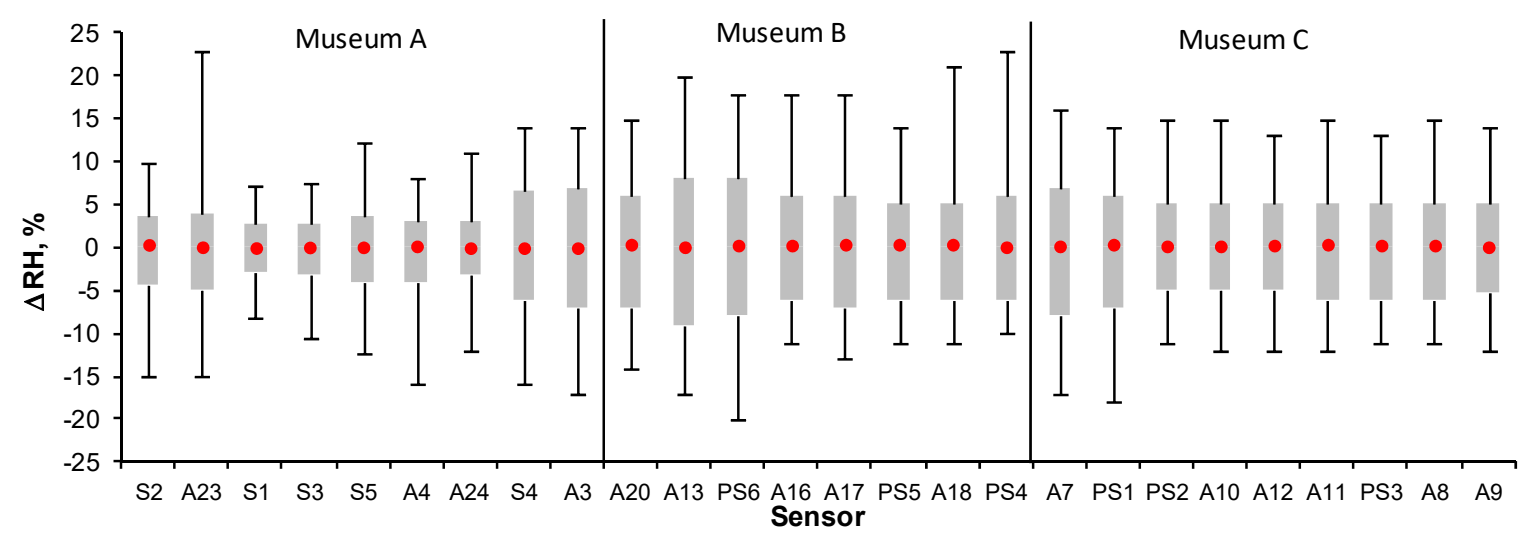

Figure 6. RH fluctuations: annual median (in red), 7th and 93rd percentiles (box) and maximum fluctuations (whiskers) based on 30-day average values, according to EN 15757 standard [6].

\subsubsection{Relative Humidity}

In museums A and B in winter the lowest recorded air humidity values were at a level of $10-13 \%$, which was caused by a large increase in internal temperature even above $25^{\circ} \mathrm{C}$. Data have shown that, during the entire winter season, the relative humidity in all analyzed museums remained at a level of $30-40 \%$, which is a typical level for heated buildings with natural ventilation located in a moderate climate. Increasing the relative humidity is not possible without additional humidification. However, the operation of a portable air humidifier in the painting gallery in museum A proved to be relatively energy-consuming. This shows that, in many cases, local humidification is a very expensive and not a sufficient solution.

The largest instantaneous deviations from the average relative humidity were noted in the summer. In that season, the relative humidity values in exhibition halls shifted upwards by $12-37 \%$ and maximum values in many locations exceeded $70 \%$. The coldest month outside the heating season was September, with an average outdoor temperature of $13.3^{\circ} \mathrm{C}$. This caused that the internal temperature dropped in museum rooms below $18^{\circ} \mathrm{C}$ (mainly in museum A), which resulted in a significant increase in relative humidity above $70 \%$. In such a situation, the dehumidification process should be employed. This, however, is another energy-consuming process. Reducing high humidity could represent a big financial burden for museums, which often have a very limited budget.

It should also be noted, that despite the use of a humidifier in the painting exhibition of Museum A, a low relative humidity during the heating season could not be avoided. In the winter months, from December to February, a relative humidity value in this room was similar to the value measured in other rooms. Humidity fell below $30 \%$ in winter, the lowest value-below $20 \%$-was observed in January. It shows the disadvantages of the manually controlled humidifier. Operation of these devices should be monitored continuously, which is very difficult without automatic adjustment. On the other hand, automatically controlled fan-coils allowed to maintain the relatively constant temperature (for $50 \%$ of year temperature was in range $20-21{ }^{\circ} \mathrm{C}$, see Figure 5) compared to other rooms in this museum (where the radiators are used), but they increased the relative humidity fluctuations, especially in winter.

The largest daily relative humidity variation was recorded in museums B and C (Table 4). In Museum C, depending on the location, relative humidity fluctuations exceeding $5 \%$ occurred, for $21 \%$ to even $64 \%$ of the measurement time. Large fluctuations were also recorded in the painting exhibition in Museum A with the fan-coil, as discussed earlier. Fluctuations exceeding $5 \%$ appeared here for $64 \%$ of the time, and these exceeding $10 \%$ for more than half of the measuring time. Daily fluctuations in relative humidity in this room reached up to $20 \%$. For comparison, in the ethnography room in the same museum, the relative humidity fluctuations (on average for all sensors) during $89 \%$ of measurement days were in the range up to $5 \%$. It should also be emphasized that the exhibition 
halls noted daily fluctuations exceeding $20 \%$. Considering mechanical damage, one large deviation is enough to cause damage.

The annual cycle analysis (Figure 6) confirmed the best humidity conditions in the non-air-conditioned rooms in Museum A. For $86 \%$ of the time, the fluctuations from the 30-day average did not exceed $\pm 5 \%$. In the other museums, they did not exceed the maximum value of $\pm 10 \%$ recommended in EN 15757 standard [6].

\subsubsection{Temperature}

The temperature time series were similar in rooms without cooling. The lowest temperature below $14{ }^{\circ} \mathrm{C}$ was recorded in Museum A. In Museum B the temperature dropped below $16^{\circ} \mathrm{C}$. The most stable conditions in winter season were found in Museum C. Here, the temperature usually did not fall below $18^{\circ} \mathrm{C}$, probably due to very thick external walls, resulting in substantial heat accumulation (Figure 5). In Museum C, the heating system also operates the most efficiently. The air heating system, due to the low thermal inertia, reacts quickly to changes in thermal loads. Performed studies have shown, that in the winter season, with operating heating system in museums (even in the case of museum A), temperature stability is much higher than in the summer. In the summer, with heating off, the room temperature was much more dependent on external weather conditions. This caused large temperature fluctuations throughout the season - usually from around $20^{\circ} \mathrm{C}$ up to $28^{\circ} \mathrm{C}$. In Museum $\mathrm{A}$ and in the tower of Museum C, where the walls were the thinnest, this range was from around 18 to $30{ }^{\circ} \mathrm{C}$. The differences between extreme temperatures in winter were smaller by $5-7^{\circ} \mathrm{C}$, in comparison with the summer season. The spread of data between the 25th and 75th percentiles for all measuring locations is higher in summer than in winter, on average by $2{ }^{\circ} \mathrm{C}$ (Table 3 ).

A different time course of air temperature was observed for the mining exhibition in Museum B (located in the basement), as well as for the air-conditioned painting exhibition in Museum A. In the case of mining exhibition, the differences were observed mainly outside of the heating season. The average temperature was lower than in other museum rooms. In contrast, the relative humidity values at this exhibition were, on average, the highest in the entire building, and often exceeded $70 \%$. In July, humidity exceeded even $80 \%$. This situation was caused by the location of the exhibition in the basement of the building which prevented the heat flow from the outside. In the case of an air-conditioned painting exhibition in Museum A, temperatures during the day were subject to slight fluctuations. In this room, both sensors registered a maximum temperature equal to $25.4^{\circ} \mathrm{C}$ in March, when, despite the larger heat gains, the fan-coils were still operating in their heating function. The operation mode of fan-coils from heating to cooling was switched manually only once a year. If the air conditioning system is set only for heating and it does not automatically switch to cooling, it can cause overheating of rooms during warmer weather episodes in the heating season. Similar problems at the turn of the seasons were also noted in other exhibition halls. During the early stages of the warm season, when the heating system is off, the indoor temperature may drop even below $19^{\circ} \mathrm{C}$. If the museum building has both heating and cooling systems, their operation should be as flexible as possible, and they should allow rooms' heating and cooling throughout the year.

The analysis of daily temperature fluctuations showed that, in exhibition halls, temperature fluctuations do not exceed $2^{\circ} \mathrm{C}$ for the major part of the year (over 90\%). Only in two non-air-conditioned rooms fluctuations up to $2{ }^{\circ} \mathrm{C}$ occurred slightly more often (Table 4). Museums B and C with thicker walls and smaller windows perform better in this respect. The large daily fluctuations in temperature occurred in the flora and fauna exhibition room at Museum A. They occurred mainly in the summer months, when the sensor could additionally heat up due to its location-it was placed on the wall separating the room from the window zone (see Section 3.4). In Museum C, with the exception of rooms on the ground floor, the most common daily temperature fluctuations are in the range of $0.5-1.0^{\circ} \mathrm{C}$. In the case of an air-conditioned painting exhibition, higher daily temperature fluctuations were noted. Fluctuations exceeding $2{ }^{\circ} \mathrm{C}$ occurred for $11 \%$ of the year at the $\mathrm{A} 3$ sensor. A difference in minimum and maximum daily temperature of $4.5^{\circ} \mathrm{C}$ was also noted twice. 
The current study showed that using only heating in winter is not sufficient to ensure stable microclimate conditions. The greatest difficulties in maintaining air parameters within the recommended ranges were noted during the summer. Expected values of indoor air parameters could be achieved by the application of automatic control system that responds quickly to temporary temperature changes and allows the heating system to be switched on also in colder periods of the summer season. Simulations performed on the numerical model of museum A, published in an article of Ferdyn-Grygierek [52], showed that stabilization of the internal temperature in winter at $20{ }^{\circ} \mathrm{C}$ could reduce monthly heat demand by up to $16 \%$. Maintaining the desired indoor temperature during the summer, not exceeding e.g., $24{ }^{\circ} \mathrm{C}$, will increase energy consumption, compared to the existing one, as it will require a supply of cold to museum halls. However, the amount of energy for cooling is several times smaller, compared to the energy needed to heat the building. A detailed analysis of indoor environment quality in Museum A and its effect on heating and cooling demand can be found in $[52,53]$.

Most available heating and cooling systems can maintain their design conditions when no major changes in internal and external loads are present. For historical buildings intended for museums, the thermal load associated with external conditions changes very slowly, as a consequence of the buildings' heavy structure. High thermal inertia results in good suppression of temporary thermal gains. However, the heterogeneous flow of people can cause sudden and significant changes in microclimatic parameters in the museum environment. In such local museums, as discussed in this study, the average number of visitors is not high, which can "diminish the vigilance" of art conservators. However, if more numerous groups of school trips occur, their presence can cause a sudden temporary change of indoor air parameters. In such museums, ensuring a proper microclimate maybe even more difficult than in other facilities, where the flow of visitors is larger, but more constant, and therefore easier to account for.

\subsection{Impact of Internal Heat and Moisture Gains}

In situ observations were conducted to identify the actual effect of visitors' presence and the lights under real, typical operating conditions of the investigated museums. They included recording of number of visitors, the time they spent in exhibition halls and the lighting status. It was revealed that individual visitors most often visited a given exhibition for $15 \mathrm{~min}$. It was also observed that they focused on one or up to several exhibitions and did not visit the entire museum. If these were organized museum lessons, the time spent by the school group was between 45 and 90 min. Lighting in all analyzed museums was turned on before the visitors entered the exhibition and turned off only after the visitors left the exhibition rooms. Although the total heat flow from lighting reached up to several $\mathrm{kW}$, its total usage time did not exceed $2 \mathrm{~h}$ a day and did not have a significant impact on the temperature of individual rooms. The exception was a small room on the ground floor of Museum C, where the display of a "skeletal grave" was illuminated by halogen lamps. In this room, the indoor temperature was almost always nearly $3{ }^{\circ} \mathrm{C}$ higher than in neighbouring rooms, with a maximum temperature of $29^{\circ} \mathrm{C}$.

Based on the comparative analysis of the measurement results in all of the analyzed museums, it was noted, that the presence of individual visitors had only a small impact on the hygrothermal conditions. Periodic increases in internal temperature (by up to $2{ }^{\circ} \mathrm{C}$ ) and relative humidity (up to $4 \%$ ) were observed only in the case of the presence of organized groups. This effect is illustrated in Figure 7. In Museum A typical relative humidity fluctuations of several \% occurring during the visitors' stay were observed on all floors of the museum. Fluctuations observed in the painting exhibition room (Figure 7) result from the operation of a portable humidifier and the ceiling fan-coil. In Museum B, one could observe a rapid increase in indoor air parameters while people were visiting the ethnographic exhibition room. At a time when the museum was closed for visitors, the internal air temperature remained almost constant, with fluctuations not exceeding $1.5^{\circ} \mathrm{C}$. This was due to the fact that the radiators were equipped with thermostatic valves. The value of relative humidity 
increased significantly only during the lessons and before the last group left the museum. In Museum C, the heating system was equipped with local control (thermostats). The temperature fluctuations were small, and they did not exceed $1{ }^{\circ} \mathrm{C}$. Only in a historical exhibition, during the "museum lessons", the increase of temperature from $20.8^{\circ} \mathrm{C}$ to $21.4^{\circ} \mathrm{C}$ coincided with the temporary presence of groups of students in that room. In turn, relative humidity peaks occurred on all floors of the museum around 11 a.m., when people were present in the building.
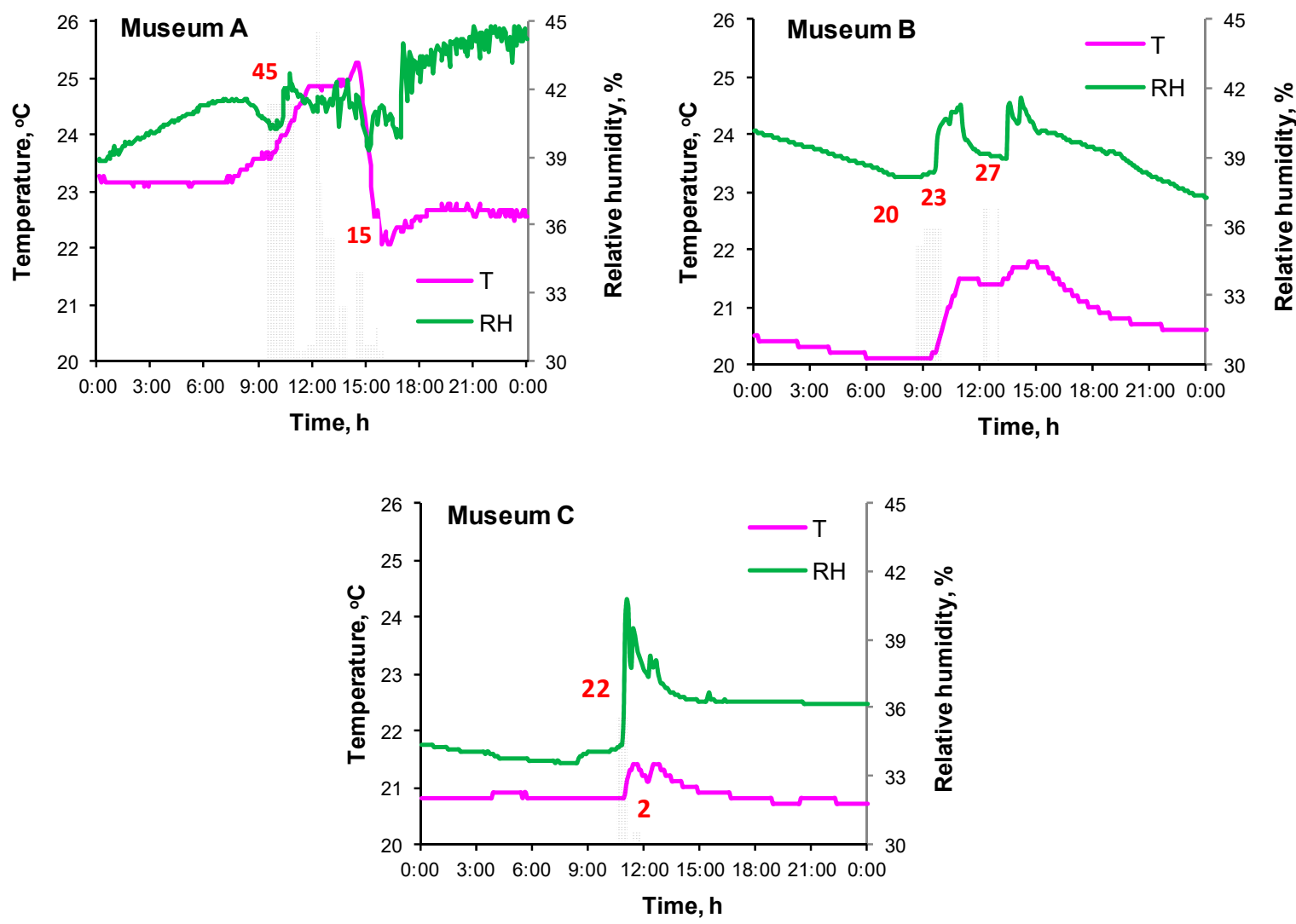

Figure 7. Comparison of indoor air parameters changes with the number of visitors in the museum for a selected day of measurements for analyzed museums: Museum A-painting exhibition, Museum B - ethnography exhibition and Museum C-historical exhibition. Numbers in red indicate visitor numbers.

Summing up this part of the research, it can be concluded, that the presence of visitors had an expected impact on the temperature and humidity conditions in museums. The higher the attendance of people, the greater impact on indoor air parameters was observed. In the case of relative humidity, the relationship has always been directly proportional to the number of visitors. In extreme cases, an increase in relative humidity up to $10 \%$ per hour was observed, with an internal temperature increase of $1{ }^{\circ} \mathrm{C}$ per hour. It should be noted, that the surveyed museums, however typical for the region, did not enjoy high attendance of people. It should be noted that it is not possible to determine the precise quantitative impact of visitors and lighting on the T and RH fluctuations, because in situ measurements cannot eliminate the impact of the external environment in the same time. However, the research has highlighted the trends.

\subsection{Impact of External Heat and Moisture Gains}

Analyses were carried out for the period from May to September, i.e., outside of the heating season. There is no air conditioning system in the studied museums (except for the painting exhibition at Museum A). Because relative humidity depends, to a large extent, on air temperature, the comparison of internal and external conditions was carried out on the basis of calculated moisture content values of 
$\mathrm{H}_{2} \mathrm{O}$ in grams per kg of dry air. Calculations were made based on relative humidity, temperature and pressure of air in the room [54]. In order to demonstrate a possible relationship between the outside and the inside environment and eliminate the impact of internal heat and moisture gains, only the data recorded on days when the museum was closed to the public were used for analysis. For our analysis, these were all Mondays. The 24-h average values from the whole summer allowed to compare the buildings in general, because $\mathrm{T}$ and $\mathrm{RH}$ fluctuations were recorded in all three buildings, but the share of external loads in each case could have been different.

The relation between indoor and outdoor temperature and humidity variations is shown in Figures 8 and 9. Points on the graphs show average daily temperature and moisture content values for unoccupied days from May to September. During the analyzed period, the external temperature varied in the range of $7-30{ }^{\circ} \mathrm{C}$ and the moisture content was in the range of $6-11 \mathrm{~g} / \mathrm{kg}$. At the same time, the internal temperature in the exhibition hall rooms has changed in a much narrower range, from approximately $18^{\circ} \mathrm{C}$ to $28^{\circ} \mathrm{C}$.
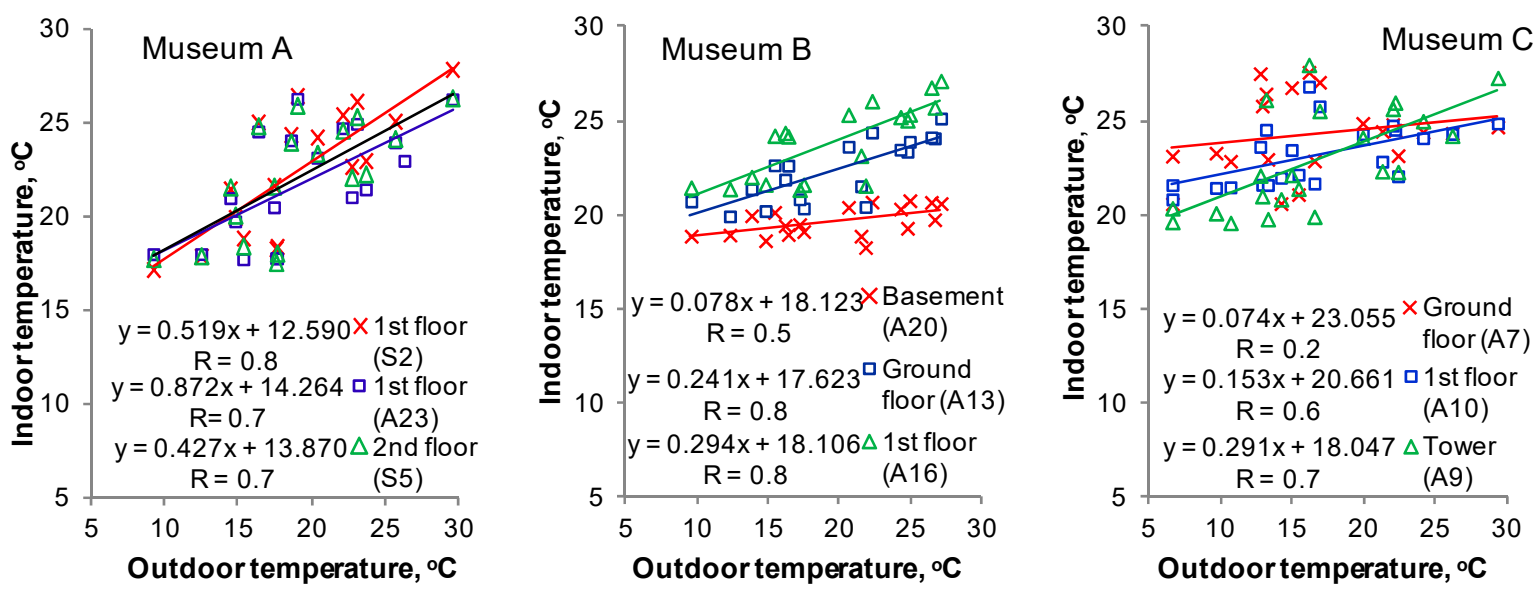

Figure 8. Correlation between internal and external temperature in the museums. Points on the graphs represent mean daily values for all unoccupied days from May to September.
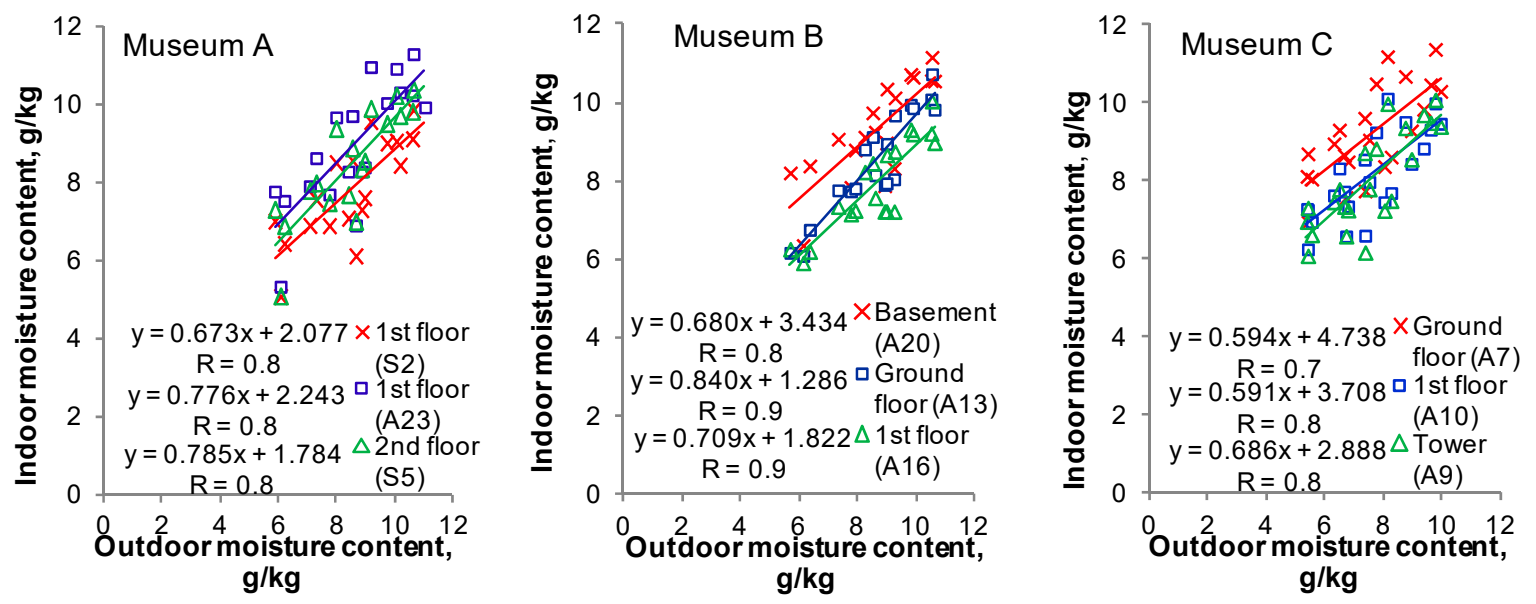

Figure 9. Correlation between internal and external moisture content in the museums. Points on the graphs represent mean daily values for all unoccupied days from May to September.

In all museum rooms, the average daily internal air temperature followed the changes in external temperature. The largest increase in indoor temperature, due to increased outdoor temperature, was observed in Museum A (the highest directional coefficients in correlation equations). As one would expect in Museum $C$ with the thickest walls and completely covered windows, temperature correlations are the weakest. Museums A and B are buildings with thin walls and large windows. 
The detailed analyses were carried out for shorter $24 \mathrm{~h}$ periods (four Mondays in June) in museums A and B. Hourly average temperature and relative humidity values recorded outside and inside of museums A and B are presented in Figures 10 and 11, correspondingly. For the first (I) and the last (IV) Monday, one can observe a typical time course of the outside air temperature for the summer season. At night, the temperature was low, in the range of $18-19^{\circ} \mathrm{C}$, while during the day it gradually increased above $26^{\circ} \mathrm{C}$. A similar trend was observed for the third Monday, but the amplitude was lower. The second Monday in June was characterized by a gradual and continuous fall in the outside temperature. The temperature change was about $5{ }^{\circ} \mathrm{C}$.

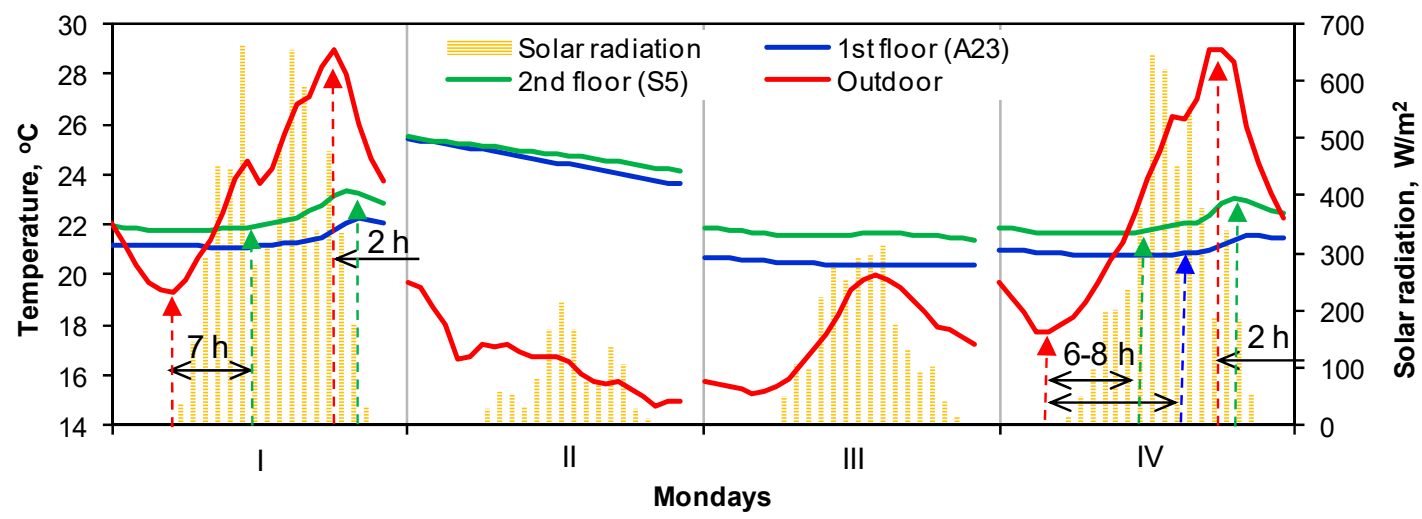

(a)

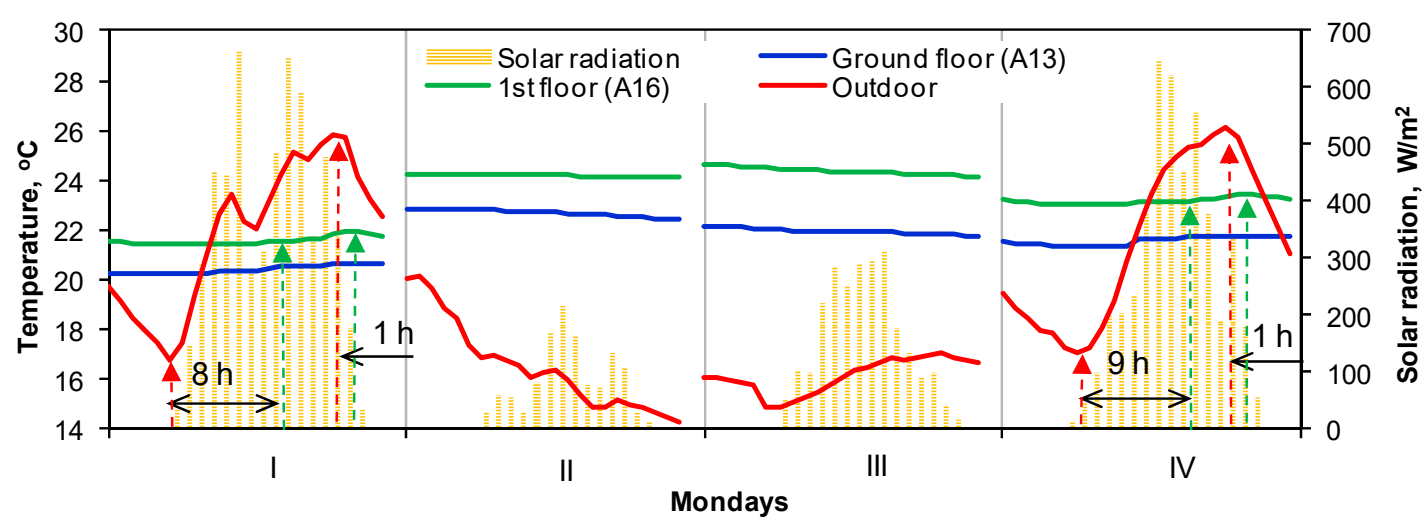

(b)

Figure 10. Variation of solar radiation and internal and external temperature for four Mondays of June in the selected locations in Museum A (a) and in Museum B (b). Data on the graph represent mean hourly values.

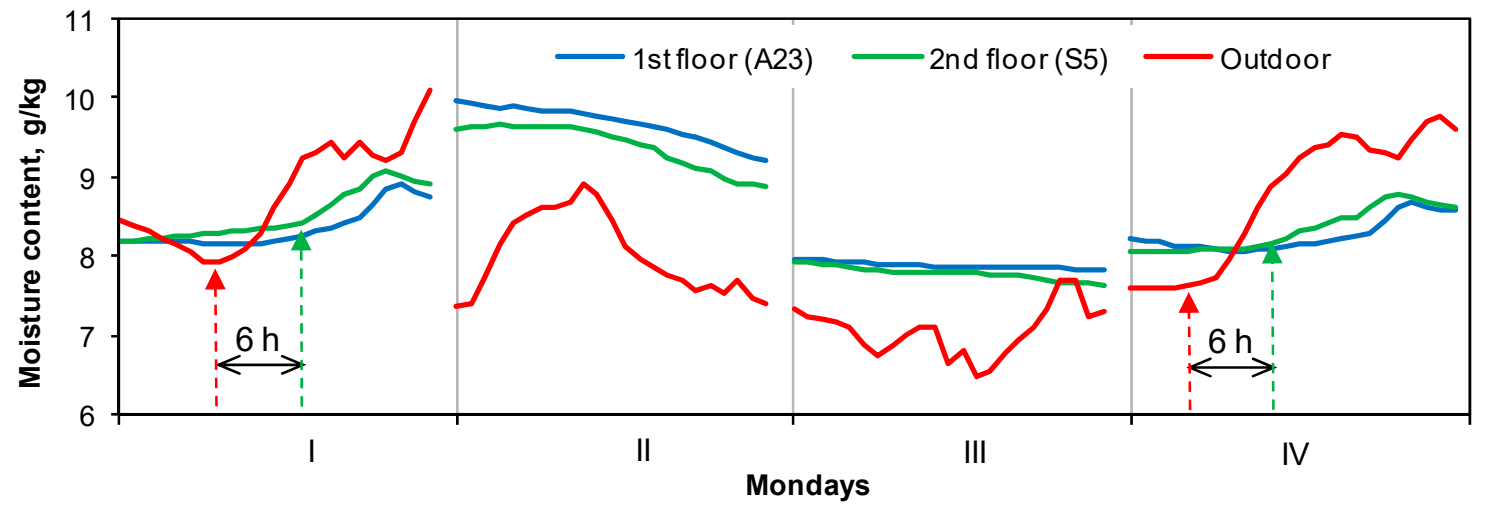

Figure 11. Variation of internal and external moisture content for four Mondays of June in the selected locations in Museum A. Data on the graph represent mean hourly values. 
A significant increase $\left(10^{\circ} \mathrm{C}\right)$ in the outside temperature in the first and fourth week of June caused an increase in indoor temperature by $1{ }^{\circ} \mathrm{C}$ in the exhibition halls of museum $\mathrm{A}$. In the second week, when the outside temperature was falling, the largest indoor temperature change, on average $1.9^{\circ} \mathrm{C}$, was recorded in non-air-conditioned rooms. The windows in most rooms are covered therefore direct solar gain is negligible. Thus the dominant heat gain is through opaque partitions. The effect of the increase of external temperature and the action of solar radiation is visible in the rooms only after a few hours from the moment of the increase of external $\mathrm{T}$ and the appearance of solar radiation (6-9 $\mathrm{h}$ depending on the room and museum). In museum B the internal temperature amplitude is much smaller. The maximum value of $\mathrm{T}$ in the rooms is delayed by one to two hours in relation to the external T peak. Both analyzed rooms in Museum A and the room with sensor A16 in Museum B have a western exposure, so the temperature drop in the room is correlated with the reduced solar radiation.

On the second analyzed Monday, the initial indoor temperature was high, despite the low outside temperature. It was caused by very hot days in the proceeding period from 9th to 12th of June, when temperatures during the day exceeded $30^{\circ} \mathrm{C}$, as shown in Figure 12. The heat accumulated in the walls was gradually released when the outdoor temperature decreased, causing the delay in the indoor temperature drop.

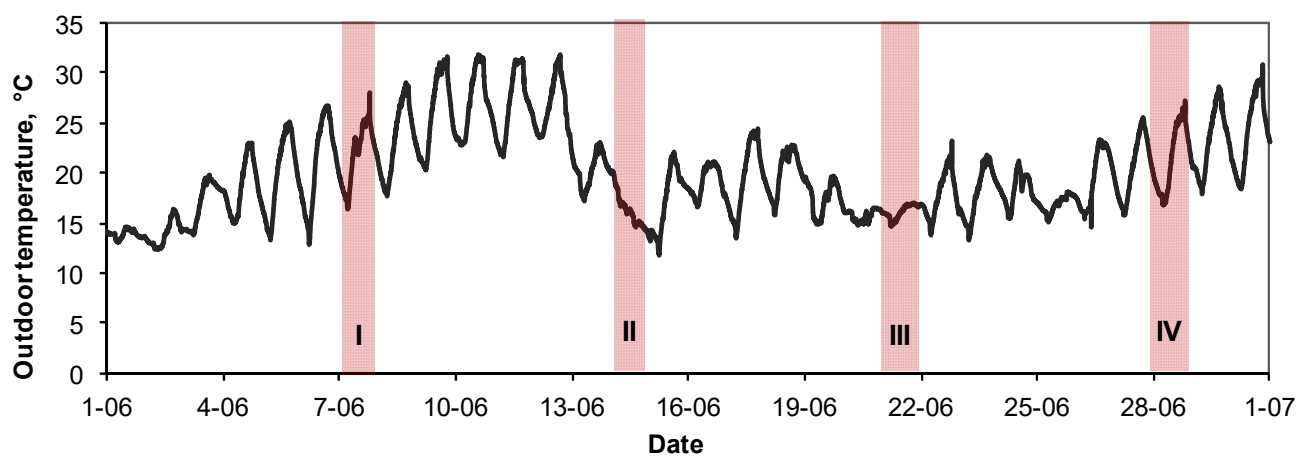

Figure 12. Variation of external temperature at Museum B in June. The analyzed Mondays are marked in red.

An interesting inverse proportionality was obtained in the third week, when, after the indoor temperature increased, due to earlier warm weather, the buildings gradually cooled down, which can be evidenced by the time course of external temperature. On this day, the outside temperature did not substantially change.

The impact of moisture content in outdoor air on humidity conditions in rooms is more pronounced than the effect of outdoor air temperature on temperature indoors. The moisture is transported mainly by ventilation air. The ventilation air supplied to the building is not treated in any way, i.e., dried or humidified. Therefore the moisture content transferred from the outside in ventilation air stream is directly reflected by changes of the inside air humidity. In all three buildings, the directional correlation coefficients of the average daily humidity content are above 0.6 .

In the case of changes in the moisture content of the indoor air, quite a large overtaking of the moisture content of the outdoor air can be observed. The highest correlation was obtained in weeks one and four when the outdoor moisture content showed an upward trend during the day (amplitude above $2.2 \mathrm{~g} / \mathrm{kg}$ ). In these cases, it is possible to see the beginning of growth of RH inside and outside as well as a clear time delay. The worst correlations were obtained in the third week, which, similarly to the temperature indications, was caused by a very small variation in the moisture content of the outdoor air (maximum $1.2 \mathrm{~g} / \mathrm{kg}$ ). In the ethnography room of Museum A (sensor S5) even an inversely proportional correlation was then obtained (Figure 11).

The analysis presented indicated some general dependencies in the studied museums. Therefore, the mechanisms of the outdoor climate's impact on the indoor environment are complex and require further in-depth analysis, including numerical research. 


\subsection{Sun Shades and Their Impact on Exhibits}

In all studied museums, sun protection in windows was used to prevent direct solar radiation from penetrating inside. Only in Museum A, in the rooms of ethnographic, flora and fauna, as well as temporary exhibitions, special solar screens made of chipboard or plasterboard were used as the exhibition spaces. An example of such a solar screen in the ethnographic exhibition room is shown in Figure 13a. Figure 13b shows an uneven temperature distribution on the back of this wall. In contrast, Figure $13 \mathrm{c}$ shows a fragment of the front side of the wall, on which the images of various techniques were hung. An image from a thermal imaging camera was superimposed on the photo, showing the unevenness of the wall heating and the images themselves.

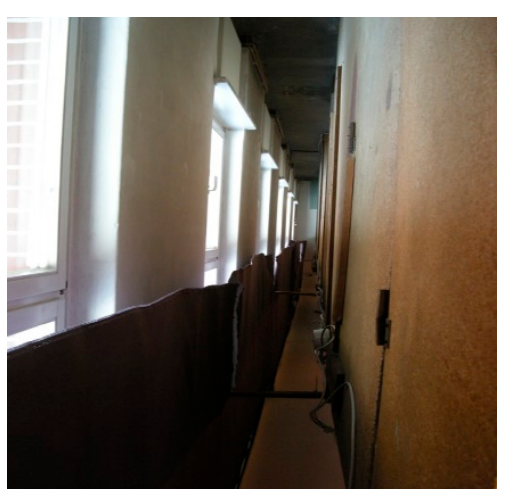

(a)

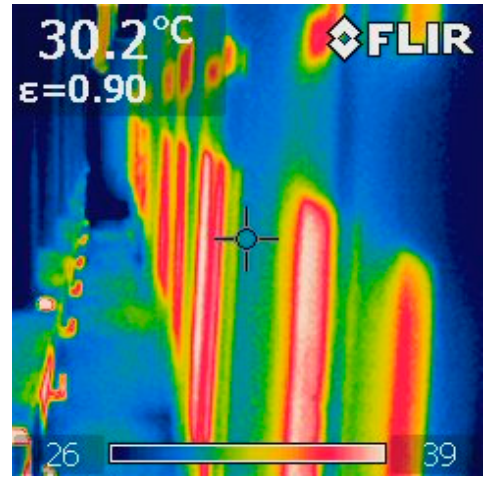

(b)

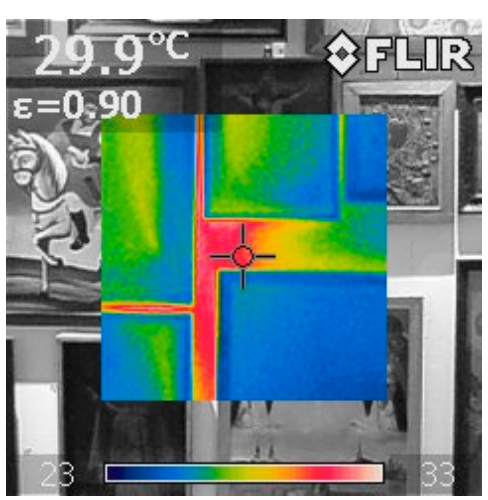

(c)

Figure 13. The curtain wall view (a) and the thermal imaging camera pictures taken for the same place-in the back (b) and the front (c) (the ethnography exhibition hall in Museum A).

Figure 14 shows the temperature-time course recorded in Museum A (by sensor S2) during two days when the museum was closed for visitors (i.e., only external factors affected temperature fluctuations in that period). Sensor S2 was placed directly on the curtain wall in the nature exhibitions room. The large immediate increase of temperature by $4{ }^{\circ} \mathrm{C}$ was directly correlated with the increase in outside temperature, as well as the increase in solar radiation. The windows of this room have western exposure.

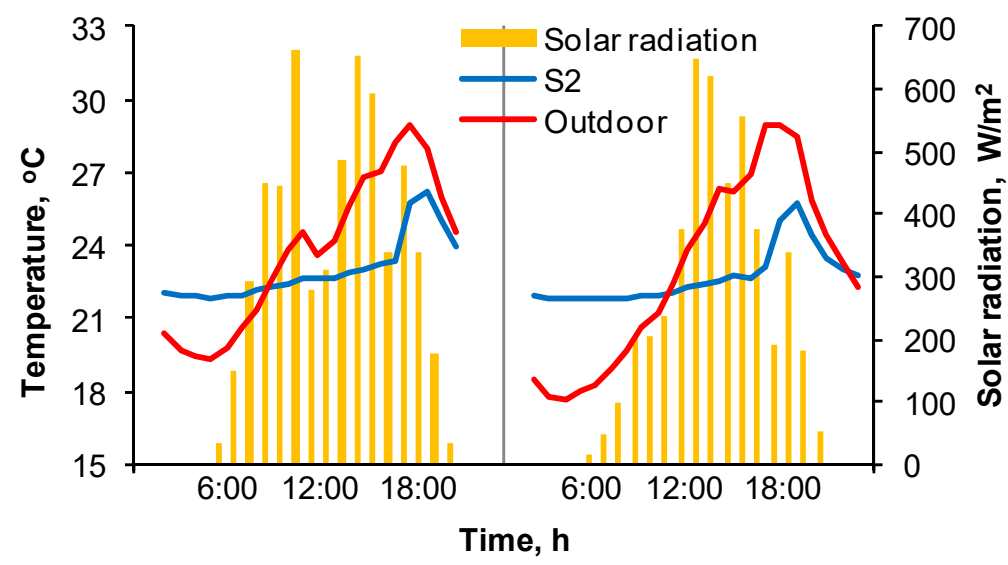

Figure 14. Variation of temperature for sensor S2 localized in Museum A on the curtain wall in the flora and fauna exhibition hall and external temperature and solar radiation for two Mondays of June.

The use of solar screen walls on windows that are also used as exhibition walls is a good way to protect museum rooms against direct solar radiation. However, such a solution may intensify the impact of the external environment on museum exhibits. The wall surface heats up from direct 
sunlight, as well as (during the heating period) from radiators located directly under the windows. The location of exhibits sensitive to temperature changes on these walls is thus unfavourable.

\section{Conclusions}

- The profile of internal hygrothermal loads in exhibition halls varied over time, which resulted in a temporary variation of the indoor environment parameters. Individual visitors have only a slight impact on the indoor climate; however, during the presence of organized groups (e.g., museum lessons), a noticeable increase in temperature and relative humidity was recorded. The recorded increase in the relative humidity after the visit of a large group of people was about 3 to $5 \%$. Increase of the temperature was between $2{ }^{\circ} \mathrm{C}$ and $4^{\circ} \mathrm{C}$.

- Lighting that is turned on only when visitors are present, had little effect on the room air temperature. However, halogen lights, which were permanently turned on, caused a noticeable increase in room air temperature (up to $3^{\circ} \mathrm{C}$ ).

- The cooling system (painting gallery in Museum A) was able to compensate for the increase in temperature caused by the presence of a large group of people but was not able to maintain constant relative humidity. Nine hours after the visitors left, the relative humidity was still about $6 \%$ higher than before their visit.

- The indoor temperature is mainly influenced by long-term trends in outdoor temperature change, not by daily fluctuations. The influence of external air parameters on the moisture content in rooms is strong for all the tested buildings.

- Sun protection walls, placed near the windows, effectively protected the room against solar radiation, but the walls were heated up rapidly. Such walls should not be used for exhibiting temperature-sensitive objects.

- The lack of appropriate HVAC systems in the analyzed museums and the lack of automatic control in existing systems did not allow to maintain the temperature and relative humidity within appropriate limits. In the museums under study, the maximum summer air temperature values were higher than those recommended in the requirements [7]. In the winter, the parameters were maintained within a given range, except for museum A, where both too low and too high temperatures occurred. Relative humidity values in all museums exceeded the recommended range, both above and below.

- Maintaining the temperature and relative humidity in the desired ranges would require the use of ventilation and air conditioning systems and will increase energy consumption. With the use of properly configured automatic regulation, the costs of their operation do not have to be significant, which has been confirmed in other authors' studies [52,55,56].

The research was carried out in three selected museums, but it can be assumed, that similar problems with maintaining indoor microclimate occur in most local museums located in temperate climates and equipped only with standard heating and ventilation systems (radiator heating system and natural ventilation). Some of the discussed dependencies are widely known. However, this work specifies them by quantifying data for selected problems. The analysis presented in the work allowed for a better understanding of the impact of dynamic changes in heat and humidity loads on the environmental conditions in museum rooms. The results of the analyses are valuable tips for HVAC engineers and museum professionals. The presented results can also be used to develop appropriate control strategies for HVAC systems.

\section{Future Research}

Improvements in heating, ventilation and cooling systems in museums are necessary. Due to the limited budget and the lack of the possibility of introducing compact HVAC systems in many historical buildings, designers are often forced to use simple, autonomous devices (air dehumidifiers, humidifiers). A change in air temperature brings a change in relative humidity. This is why it is 
necessary to establish appropriate strategies for operating such devices with time-varying thermal and humidity loads inside and outside of the building. Numerical modelling, including CFD and building dynamic thermal simulations methods, is a useful tool to predict the effect of possible interventions on the indoor environment. The future research will focus on numerical and experimental investigations of the possibilities to apply portable devices regulating indoor air humidity in museums located in historic buildings.

Author Contributions: Literature review, study design, J.F.-G. and J.K.; methodology, M.B.; results analyses, J.F.-G. and P.L.; writing — original draft, J.F.-G., P.L. and P.K.; writing—review and editing, A.B., M.B. and J.K.; supervision, J.F.-G. and J.K. All authors have read and agreed to the published version of the manuscript.

Funding: This research received no external funding.

Acknowledgments: The work was supported by Polish Ministry of Science and Higher Education within research subsidy. All authors have read and agreed to the published version of the manuscript.

Conflicts of Interest: The authors declare no conflict of interest.

\section{References}

1. Cadelano, G.; Cicolin, F.; Emmi, G.; Mezzasalma, G.; Poletto, D.; Galgaro, A.; Bernardi, A. Improving the energy efficiency, limiting costs and reducing $\mathrm{CO}_{2}$ emissions of a museum using geothermal energy and energy management policies. Energies 2019, 12, 3192. [CrossRef]

2. Camuffo, D. Microclimate for Cultural Heritage; Elsevier Science: Amsterdam, The Netherlands, 1998.

3. Bratasz, Ł.; Łukomski, M.; Klisińska-Kopacz, A.; Zawadzki, W.; Dzierżęga, K.; Bartosik, M.; Sobczyk, J.; Lennard, F.; Kozłowski, R. Risk of climate-induced damage in historic textiles. Strain 2015, 51, 78-88. [CrossRef]

4. Rachwał, B.; Bratasz, Ł.; Krzemień, L.; Łukomski, M.; Kozłowski, R. Fatigue damage of the gesso layer in panel paintings subjected to changing climate conditions. Strain 2012, 48, 474-481. [CrossRef]

5. Jakieła, S.; Bratasz, Ł.; Kozłowski, R. Numerical modelling of moisture movement and related stress field in lime wood subjected to changing climate conditions. Wood Sci. Technol. 2008, 42, 21-37. [CrossRef]

6. EU Standard EN 15757:2010. Conservation of Cultural Property—Specifications for Temperature and Relative Humidity to Limit Climate-Induced Mechanical Damage in Organic Hygroscopic Materials; European Committee for Standardization: Brussels, Belgium, 2010.

7. American Society of Heating, Refrigerating and Air Conditioning Engineers. ASHRAE Handbook-HVAC Applications, Chapter 23: Museums, Galleries, Archives, and Libraries, SI ed.; American Society of Heating, Refrigerating and Air-Conditioning Engineers: Atlanta, GA, USA, 2015.

8. Sharif-Askari, H.; Abu-Hijleh, B. Review of museums' indoor environment conditions studies and guidelines and their impact on the museums' artifacts and energy consumption. Build. Environ. 2018, 143, 186-195. [CrossRef]

9. Lucchi, E. Review of preventive conservation in museum buildings. J. Cult. Herit. 2018, 29, 180-193. [CrossRef]

10. Lucchi, E. Multidisciplinary risk-based analysis for supporting the decision making process on conservation, energy efficiency, and human comfort in museum buildings. J. Cult. Herit. 2016, 22, 1079-1089. [CrossRef]

11. Michalski, S. The ideal climate, risk management, the ASHRAE chapter, proofed fluctuations, and towards a full risk analysis model. In Proceedings of the Experts' Roundtable on Sustainable Climate Control Strategies, Tenerife, Spain, April 2007; Available online: http://www.getty.edu/conservation/our_projects/ science/climate/paper_michalski.pdf (accessed on 16 December 2019).

12. Janssen, H.; Christensen, J.E. Hygrothermal optimisation of museum storage spaces. Energy Build. 2013, 56, 169-178. [CrossRef]

13. Litti, G.; Audenaert, A.; Fabbri, K. Indoor microclimate quality (imq) certification in heritage and museum buildings: The case study of Vleeshuis Museum in Antwerp. Build. Environ. 2017, 124, 478-491. [CrossRef]

14. Cantin, R.; Burgholzer, J.; Guarracino, G.; Moujalled, B.; Tamelikecht, S.; Royet, B.G. Field assessment of thermal behaviour of historical dwellings in France. Build. Environ. 2010, 45, 473-484. [CrossRef]

15. Fabbri, K.; Pretelli, M. Heritage buildings and historic microclimate without HVAC technology: Malatestiana library in Cesena, Italy, UNESCO memory of the World. Energy Build. 2014, 76, 15-31. [CrossRef] 
16. Ryhl-Svendsen, M.; Padfield, T.; Smith, V.A.; De Santis, F. The indoor climate in historic buildings without mechanical ventilation systems. In Proceedings of the ISIAQ 7th International Conference, Healthy Buildings 2003, Singapore, 7-11 December 2003; pp. 7-11.

17. La Gennusa, M.; Rizzo, G.; Scaccianoce, G.; Nicoletti, F. Control of indoor environments in heritage buildings: Experimental measurements in an old Italian museum and proposal of a methodology. J. Cult. Herit. 2005, 6, 147-155. [CrossRef]

18. Bertolin, C. Preservation of cultural heritage and resources threatened by climate change. Geosciences 2019, 9, 250. [CrossRef]

19. Grøntoft, T.; Marincas, O. Indoor air pollution impact on cultural heritage in an urban and a rural location in Romania: The National military museum in Bucharest and the Tismana monastery in Gorj County. Herit. Sci. 2018, 6, 73. [CrossRef]

20. Velazquez-Gomez, M.; Hurtado-Fernandez, E.; Lacorte, S. Differential occurrence, profiles and uptake of dust contaminants in the Barcelona urban area. Sci. Total Environ. 2019, 648, 1354-1370. [CrossRef] [PubMed]

21. Marchetti, A.; Pilehvar, S.; Hart, L.; Pernia, D.L.; Voet, O.; Anaf, W.; Nuyts, G.; Otten, E.; Demeyer, S.; Schalm, O.; et al. Indoor environmental quality index for conservation environments: The importance of including particulate matter. Build. Environ. 2017, 126, 132-146. [CrossRef]

22. Lamonaca, F.; Pizzuti, G.; Arcuri, N.; Palermo, A.M.; Morello, R. Monitoring of environmental parameters and pollution by fungal spores in the National Gallery of Cosenza: A case of study. Measurement 2014, 47, 1001-1007. [CrossRef]

23. Krupińska, B.; Worobiec, A.; Rotondo, G.; Novaković, V.; Kontozova, V.; Ro, C.U.; Van Grieke, R.; De Wael, K. Assessment of the air quality $\left(\mathrm{NO}_{2}, \mathrm{SO}_{2}, \mathrm{O}_{3}\right.$ and particulate matter) in the Plantin-Moretus Museum/Print Room in Antwerp, Belgium, in different seasons of the year. Microchem. J. 2012, 102, 49-53. [CrossRef]

24. Godoi, R.; Carneiro, B.; Paralovo, S.; Campos, V.; Tavares, T.; Evangelista, H.; Van Grieken, R.; Godoi, A. Indoor air quality of a museum in a subtropical climate: The Oscar Niemeyer museum in Curitiba, Brazil. Sci. Total Environ. 2013, 452-453, 314-320. [CrossRef]

25. Worobiec, A.; Samek, L.; Krata, A.; Van Meel, K.; Krupinska, B.; Stefaniak, E.; Karaszkiewicz, P.; Van Grieken, R. Transport and deposition of airborne pollutants in exhibition areas located in historical buildings-Study in Wawel Castle Museum in Cracow, Poland. J. Cult. Herit. 2010, 11, 354-359. [CrossRef]

26. Mleczkowska, A.; Strojecki, M.; Bratasz, L.; Kozlowski, R. The effect of ventilation on soiling by particles of outdoor and indoor origin in historical churches. Build. Simul. 2017, 10, 383-393. [CrossRef]

27. Mleczkowska, A.; Strojecki, M.; Bratasz, L.; Kozlowski, R. Particle penetration and deposition inside historical churches. Build. Environ. 2016, 95, 291-298. [CrossRef]

28. Bertolin, C.; Strojecki, M.; Kozłowski, R. Particle penetration, emission and deposition in the Diocesan Museum in Udine, Italy to assess soiling of Giambattista Tiepolo's wall paintings. Stud. Conserv. 2018, 63, 326-328. [CrossRef]

29. Papadopoulos, A.M.; Avgelis, A.; Anastaselos, D. Low energy cooling of the White Tower, functioning as a contemporary museum. Energy Build. 2008, 40, 1377-1386. [CrossRef]

30. Ferrarese, S.; Bertoni, D.; Dentis, V.; Gena, L.; Rinaudo, M. Microclimatic analysis in the Museum of Physics, University of Turin, Italy: A case-study. Eur. Phys. J. Plus 2018, 133, 538. [CrossRef]

31. Sciurpi, F.; Carletti, C.; Pierangioli, L. Assessment of thermo-hygrometric indicators for preventive conservation inside museums: In field monitoring and passive microclimatic control strategies applied to "la Specola" museum of Florence. IOP Conf. Ser. Mater. Sci. Eng. 2018, 364, 012023. [CrossRef]

32. Klein, L.J.; Bermudez, S.A.; Schrott, A.G.; Tsukada, M.; Dionisi-Vici, P.; Kargere, L.; Marianno, F.; Hamann, H.F.; López, V.; Leona, M. Wireless Sensor Platform for Cultural Heritage Monitoring and Modeling System. Sensors 2017, 17, 1998. [CrossRef]

33. Christensen, J.E.; Kollias, C.G. Hygrothermal evaluation of a museum storage building based on actual measurements and simulations. Energy Procedia 2015, 78, 651-656. [CrossRef]

34. Becherini, F.; Bernardi, A.; Frassoldati, E. Microclimate inside a semi-confined environment: Valuation of suitability for the conservation of heritage materials. J. Cult. Herit. 2010, 11, 471-476. [CrossRef]

35. Strada, M.; Carbonari, A.; Peron, F.; Porciani, L.; Romagnoni, P. The microclimate analysis of tezone ' 105 ' of the Venetian Arsenale. J. Cult. Herit. 2002, 3, 89-92. [CrossRef] 
36. Martens, M.H.J. Climate Risk Assessment in Museums: Degradation Risks Determined from Temperatureand Relative Humidity Data. Ph.D. Thesis, Eindhoven University of Technology, Eindhoven, The Netherlands, 2012. Available online: https://pure.tue.nl/ws/files/3542048/729797.pdf (accessed on 16 December 2019).

37. Camuffo, D.; Van Grieken, R.; Busse, H.; Sturaro, G.; Valentino, A.; Bernardi, A.; Blades, N.; Shooter, D.; Deutsch, F.; Wieser, M.; et al. Environmental monitoring in four European museums. Atmos. Environ. 2001, 35, 127-140. [CrossRef]

38. Luciani, A. Historical Climates and Conservation Environments. Historical Perspectives on Climate Control Strategies within Museums and Heritage Buildings. Ph.D. Thesis, Polytechnic University of Milan, Milan, Italy, 2013. Available online: https://www.academia.edu/3505879/Historical_climates_and_conservation_ environments._Historical_perspectives_on_climate_control_strategies_within_museums_and_heritage_ buildings (accessed on 16 December 2019).

39. Baranowski, A.; Ferdyn-Grygierek, J. Numerical prediction of the air exchange in the museum premises equipped with natural ventilation systems. In Proceedings of the 33rd AIVC Conference and 2nd TightVent Conference, Copenhagen, Denmark, 11 October 2012; pp. 101-103.

40. EU Standard EN 15758:2010. Conservation of Cultural Property_Procedures and Instruments for Measuring Temperatures of the Air and the Surfaces of Objects; European Committee for Standardization: Brussels, Belgium, 2010.

41. EU Standard EN 16242:2012. Conservation of Cultural Heritage-Procedures and Instruments for Measuring Humidity in the Air and Moisture Exchanges between Air and Cultural Property; European Committee for Standardization: Brussels, Belgium, 2012.

42. Davis Health EnviroMonitor. Available online: https://www.davisinstruments.com/solution/enviromonitoraffordable-field-monitoring-system/ (accessed on 1 June 2019).

43. Fanger, P.O. Thermal Comfort; Arkady: Warsaw, Poland, 1974. (In Polish)

44. McIntyre, D.A. Indoor Climate; Applied Science Publishers, Ltd.: London, UK, 1980.

45. Recknagel, H.; Schramek, E.R. Handbook. Heating, Air Conditioning, Domestic Hot Water, Refrigerator Technology; Omni Scala: Wrocław, Poland, 2008. (In Polish)

46. ASHRAE. ASHRAE Handbook, Fundamentals, SI ed.; American Society of Heating, Refrigerating and Air Conditioning Engineers: Atlanta, GA, USA, 1997.

47. ISO Standard 9164:1989. Thermal Insulation—Calculation of Space Heating Requirements for Residential Buildings; International Organization for Standardization: Geneva, Switzerland, 1989.

48. Ferdyn-Grygierek, J.; Lubina, P.; Kaczmarczyk, J. Analysis of visitors impact on the museum rooms microclimate. In Proceedings of the 2017 Healthy Buildings Europe, Lublin, Poland, 2-5 July 2017.

49. Ascione, F.; Bellia, L.; Capozzoli, A.; Minichiello, F. Energy saving strategies in air-conditioning for museums. Appl. Therm. Eng. 2009, 29, 676-686. [CrossRef]

50. Corgnati, S.P.; Fabi, V.; Filippi, M. A methodology for microclimatic quality evaluation in museums: Application to a temporary exhibit. Build. Environ. 2009, 44, 1253-1260. [CrossRef]

51. Silva, H.E.; Henriques, F.M.A.; Henriques, T.A.S.; Coelho, G. A sequential process to assess and optimize the indoor climate in museums. Build. Environ. 2016, 104, 21-34. [CrossRef]

52. Ferdyn-Grygierek, J. Indoor environment quality in the museum building and its effect on heating and cooling demand. Energy Build. 2014, 85, 32-44. [CrossRef]

53. Ferdyn-Grygierek, J. Monitoring of indoor air parameters in large museum exhibition halls with and without air-conditioning systems. Build. Environ. 2016, 107, 113-126. [CrossRef]

54. Korotcenkov, G. Handbook of Humidity Measurement: Methods, Materials and Technologies; Taylor \& Francis Group, LLC: New York, NY, USA, 2018.

55. Ferdyn-Grygierek, J.; Grygierek, K. HVAC control methods for drastically improved hygrothermal museum microclimates in warm season. Build. Environ. 2019, 149, 90-99. [CrossRef]

56. Ferdyn-Grygierek, J.; Grygierek, K. Proposed strategies for improving poor hygrothermal conditions in museum exhibition rooms and their impact on energy demand. Energies 2019, 12, 620. [CrossRef]

(C) 2020 by the authors. Licensee MDPI, Basel, Switzerland. This article is an open access article distributed under the terms and conditions of the Creative Commons Attribution (CC BY) license (http://creativecommons.org/licenses/by/4.0/). 